\title{
A Spectroscopic And Theoretical Investigation of Color Tuning in Deep Red Luminescent Iridium(III) Complexes
}

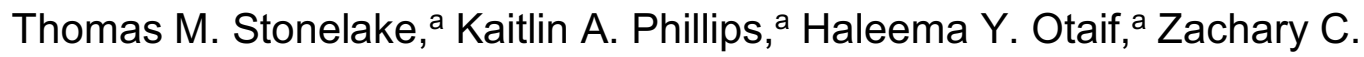
Edwardson, ${ }^{a}$ Peter N. Horton, ${ }^{b}$ Simon J. Coles, ${ }^{b}$ Joseph M. Beames, ${ }^{\text {a* }}$ and Simon

$$
\text { J.A. Pope }{ }^{a *}
$$

aSchool of Chemistry, Main Building, Cardiff University, Cardiff CF10 3AT, Cymru/Wales, UK; bUK National Crystallographic Service, Chemistry, Faculty of

Natural and Environmental Sciences, University of Southampton, Highfield, Southampton, SO17 1BJ, England, UK.

Email: popesj@cardiff.ac.uk; beamesj@cardiff.ac.uk

\begin{abstract}
A series of heteroleptic, neutral iridium(III) complexes of the form $\left[\operatorname{Ir}(\mathrm{L})_{2}\left(\mathrm{~N}^{\wedge} \mathrm{O}\right)\right]$ (where $\mathrm{L}=$ cyclometalated 2,3-disubstituted quinoxaline; $\mathrm{N}^{\wedge} \mathrm{O}=$ ancillary picolinate or pyrazinoate) are described in terms of their synthesis and spectroscopic properties, with supporting computational analyses providing additional insight to the electronic properties. The ten $\left[\operatorname{Ir}(\mathrm{L})_{2}\left(\mathrm{~N}^{\wedge} \mathrm{O}\right)\right]$ complexes were characterised using a range of analytical techniques (including ${ }^{1} \mathrm{H},{ }^{13} \mathrm{C},{ }^{19} \mathrm{~F}$ NMR, IR spectroscopies and mass spectrometry). One of the examples was structurally characterised using X-ray diffraction. Redox properties were determined using cyclic voltammetry and the electronic properties were investigated using UV-vis., time-resolved luminescence and transient absorption spectroscopies. The complexes are phosphorescent in the red region of the visible spectrum $\left(\lambda_{\mathrm{em}}=632-675 \mathrm{~nm}\right)$, with lifetimes typically of hundreds of nanoseconds and quantum yields ca. $5 \%$ in aerated chloroform. A combination of spectroscopic and computational analyses suggests that the long wavelength absorption and emission properties of these complexes are strongly characterised by a combination of spin forbidden metal-to-ligand charge transfers and quinoxalinecentered transitions. The emission wavelength in these complexes can thus be controlled in two ways: firstly, the substitution of the cyclometalating quinoxaline ligand can perturb both HOMO and LUMO levels (chlorine atoms on the ligand induce the
\end{abstract}


largest bathochromic shift), and secondly, the choice of ancillary ligand can influence the HOMO energy (pyrazinoate stabilises the HOMO, inducing hypsochromic shifts). 


\section{Introduction}

The development and study of luminescent cyclometalated iridium(III) complexes continues to attract significant attention. ${ }^{1}$ The motivation is driven by the use of such species in optoelectronic applications such as bioimaging, ${ }^{2}$ electroluminescence, ${ }^{3}$ photoredox catalysts, ${ }^{4}$ non-linear optics, ${ }^{5}$ chemosensors, ${ }^{6}$ and energy upconversion. ${ }^{7}$ Underpinning these applications is the ability to control the physical properties of the complex and, in particular, tuning 8 of the electronic properties that dictate the emission characteristics. This can be achieved by careful consideration and combination of conjugated cyclometalated ligands and the choice of ancillary ligand..$^{9}$ In this context, the vast majority of $\operatorname{Ir}(\mathrm{III})$ complexes employ five-membered chelate ligands (for example, 2-phenylpyridine) that result in either neutral or cationic ${ }^{10}$ species. A handful of reports have also detailed six-membered chelate systems that can also have attractive luminescence properties. ${ }^{11}$

The development of red-emissive $\operatorname{Ir}(\mathrm{III})$ complexes are very attractive from a number of perspectives. Firstly, interest in red emitters has been driven by the advance of white light emitting diodes, which require high purity blue, green and red emitting materials. ${ }^{12}$ The advantage of $\operatorname{Ir}(\mathrm{III})$ coordination chemistry is that ligands can be developed to tune emission across the visible light spectrum, although the purity of the emission colors can be compromised by the spectral broadness of emission bands. For this application, the development of $\operatorname{Ir}(\mathrm{III})$ red phosphors is challenging because of the inherently lower quantum efficiencies that result from a lower energy gap between ground and excited states. Red emitters are also very attractive in bioimaging disciplines using confocal fluorescence microscopy; ${ }^{13}$ the use of longer excitation and emission wavelengths tends to be more compatible with biological samples, can significantly improve imaging quality through reduced autofluorescence signals and is complementary to the plethora of commercially available dyes.

A general strategy for bathochromically shifting the emission wavelengths of $\operatorname{Ir}(I I I)$ complexes is to increase the conjugation of the chelating ligands and introduce substituents for further tuning. For example, exchanging 2-phenylpyridine for 1phenylisoquinoline (i.e. comparison of $\left[\operatorname{Ir}(\mathrm{ppy})_{3}\right]$ vs. $\left[\operatorname{Ir}(\mathrm{piq})_{3}\right]$ results in a red shift in emission for the latter to around $620 \mathrm{~nm} .{ }^{14}$ Researchers have further developed this strategy, ${ }^{15}$ including the use of various ancillary ligands. ${ }^{16}$ Indeed, a number of reports have also shown that emission wavelengths can be shifted further into the near-IR $(>750 \mathrm{~nm})$ region, although quantum efficiencies are correspondingly lower. ${ }^{17}$ Our own 
contributions have focused upon the development of substituted 2-phenylquinoline ${ }^{18}$ and 2-phenylquinoxaline ${ }^{19}$ as cyclometalating ligands. Quinoxalines, in particular, provide an adaptable ligand platform for developing red emitting $\operatorname{Ir}(\mathrm{III})$ complexes with good photostability. ${ }^{20}$

Herein, we report the development of a series of neutral, mixed ligand $\operatorname{Ir}(\mathrm{III})$ complexes (Scheme 1) where emission wavelengths can be tuned from $632-675 \mathrm{~nm}$ by simple variations in the cyclometalating quinoxaline ligand structure and choice of ancillary ligand. ${ }^{21} \mathrm{~A}$ combination of detailed spectroscopic and computational analyses have been used to unravel the origins of the luminescence behavior and fully ascribe the excited state properties, providing a working hypothesis for the rational design of complexes based on these ligands.

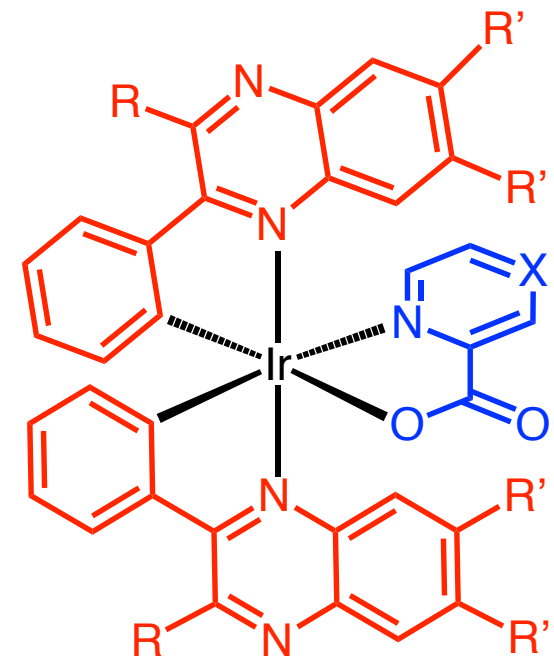

$$
\left[\mathrm{R}=\mathrm{Me}, \mathrm{Ph} ; \mathrm{R}^{\prime}=\mathrm{Me}, \mathrm{Cl}, \mathrm{F} ; \mathrm{X}=\mathrm{C}, \mathrm{N}\right]
$$

Scheme 1. The general molecular structure of the complexes under investigation. 


\section{Results and Discussion}

\section{Synthesis Of The Complexes}

The tetrasubstituted quinoxaline based ligands (L1-L7), synthesized by the simple condensation of an appropriate aryl diketone with a disubstituted 1,2phenylenediamine, have been reported previously. ${ }^{7 \mathrm{~b}}$ From these ligands, a series of chloro-bridged $\operatorname{Ir}(\mathrm{III})$ dimeric compounds of the formula $\left[\left\{\operatorname{Ir}(\mathrm{L})_{2}-(\mu-\mathrm{Cl})\right\}_{2}\right]$ were synthesised according to the traditional method first published by Nonoyama. ${ }^{22}$ Firstly, these dimeric $\operatorname{Ir}(I I I)$ species were then reacted with picolinic acid to yield the corresponding charge neutral picolinate complexes, $\left[\operatorname{lr}(\mathrm{L})_{2}(\right.$ pic $\left.)\right]$ (where $L=L 1-L 7$ ) (Fig. 1). This approach was also adopted in the isolation of selected pyrazinoate variants (Fig. 2), $\left[\operatorname{Ir}(\mathrm{L})_{2}(\mathrm{pyz})\right]$ (where $\mathrm{L}=\mathrm{L} 2, \mathrm{~L} 5$ and $\mathrm{L} 7$ ), with the exception of $\left[\operatorname{lr}(\mathrm{L} 2)_{2}(\mathrm{pyz})\right]$ where improved yields were obtained via the bis-acetonitrile adduct cis$\left[\operatorname{lr}(\mathrm{MeCN})_{2}\left(\mathrm{~L} 2_{2}\right)_{2}\right] \mathrm{BF}_{4}$. Complete experimental and synthetic details, as well as characterization data, are presented in Supporting Information. 


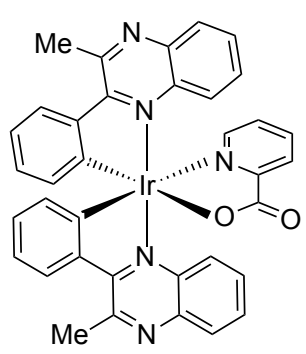

[Ir(L1) 2 (pic)]

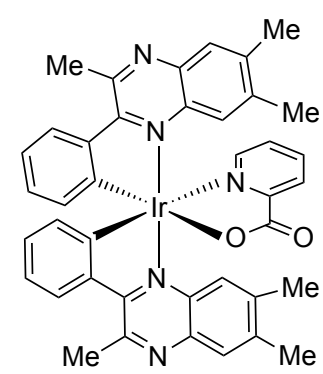

[Ir(L2) 2 (pic)]

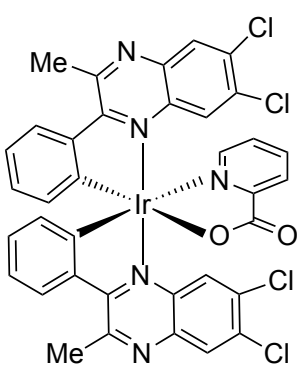

$\left[\operatorname{lr}(\mathrm{L} 3)_{2}(\mathrm{pic})\right]$

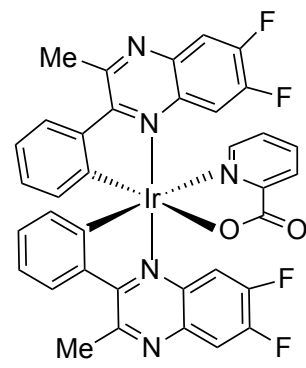

$\left[\operatorname{lr}(\mathrm{L} 4)_{2}(\mathrm{pic})\right]$

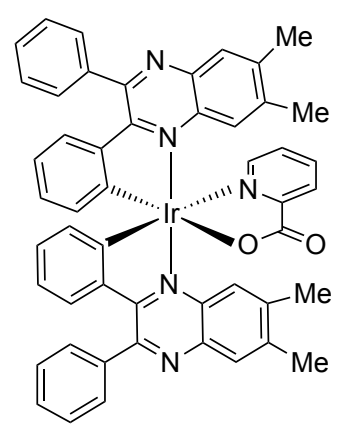

$\left[\operatorname{Ir}(\mathrm{L} 5)_{2}(\mathrm{pic})\right]$

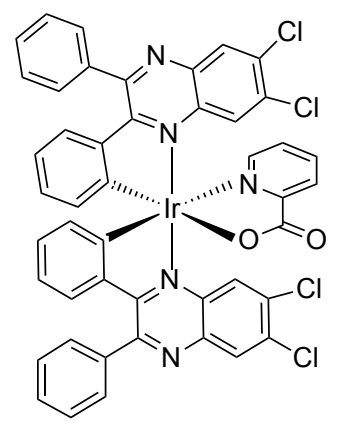

[Ir(L6) $\left.)_{2}(\mathrm{pic})\right]$

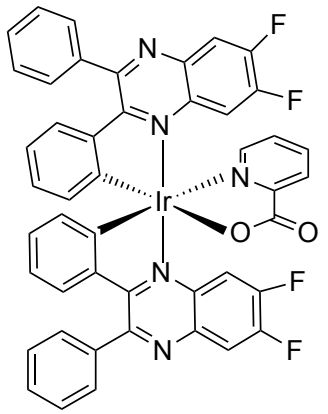

$\left[\operatorname{lr}(\mathrm{L} 7)_{2}(\mathrm{pic})\right]$

Figure 1. Structures of the mixed ligand picolinate iridium(III) complexes, $\left[\operatorname{Ir}(\mathrm{L})_{2}(\mathrm{pic})\right]$.

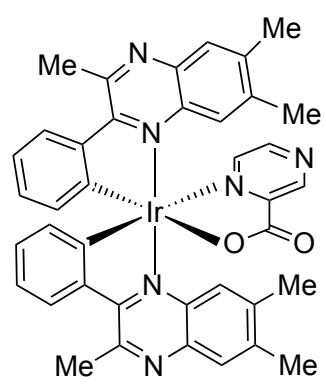

$\left[\operatorname{lr}(\mathrm{L} 2)_{2}(\mathrm{pyz})\right]$

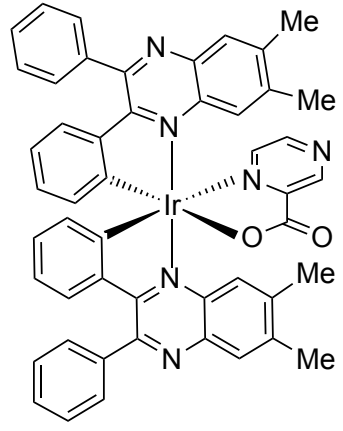

$\left[\operatorname{lr}(\mathrm{L} 5)_{2}(\mathrm{pyz})\right]$

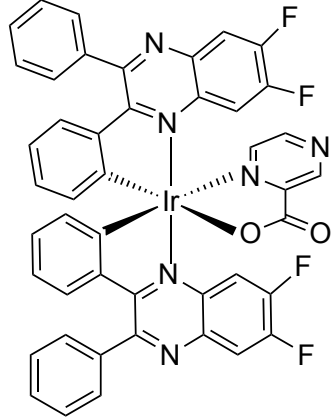

$\left[\operatorname{lr}(\mathrm{L} 7)_{2}(\mathrm{pyz})\right]$

Figure 2. Structures of the mixed ligand pyrazinoate iridium(III) complexes, $\left[\operatorname{Ir}(\mathrm{L})_{2}(\mathrm{pyz})\right]$. 


\section{Characterisation Of The Complexes}

The complexes synthesized in this study were characterized by a range of techniques including ${ }^{1} \mathrm{H},{ }^{13} \mathrm{C}\left\{{ }^{1} \mathrm{H}\right\}$ and ${ }^{19} \mathrm{~F}\left\{{ }^{1} \mathrm{H}\right\}$ NMR spectroscopy, in addition to high resolution mass spectrometry. All of the complexes showed good solubility in common organic solvents such as chloroform, acetonitrile, methanol and acetone.

The inclusion of the asymmetric picolinate or pyrazinoate ligand into the coordination sphere renders the two cyclometalated quinoxaline ligands as inequivalent. This increases the complexity of the resultant NMR spectra of these species. For example, the ${ }^{1} \mathrm{H}$ NMR spectrum of $\left[\operatorname{Ir}(\mathrm{L} 1)_{2}(\mathrm{pic})\right]$ showed two unique methyl environments ca. 3.35 ppm, as well as unique resonances for each of the quinoxaline based protons. The lack of symmetry in these complexes is apparent when compared to the spectra for the previously reported $\left[\operatorname{Ir}(L 1)_{2}(\right.$ bipy $\left.)\right] P F_{6}$ wherein the cyclometalating ligands are equivalent (Fig. S1, Supporting Information). ${ }^{7 \mathrm{~b}}$ Other general features in the ${ }^{1} \mathrm{H}$ NMR spectra include two upfield doublets ca. 6-7 ppm, which correspond to the protons ortho- to the cyclometalating carbon atom on each unique quinoxaline ligand. In the majority of cases the ${ }^{13} \mathrm{C}\left\{{ }^{1} \mathrm{H}\right\}$ NMR spectra revealed a furthest downfield resonance ca. 170 ppm, which was assigned to the carbonyl group of the coordinated picolinate or pyrazinoate ligand. The fluorine-containing complexes were also analysed via ${ }^{19} \mathrm{~F}\left\{{ }^{1} \mathrm{H}\right\}$ NMR spectroscopy and the data is presented in Table 1 alongside that of the relevant free ligands.

Table 1. Comparison of the ${ }^{19} \mathrm{~F}\left\{{ }^{1} \mathrm{H}\right\}$ NMR data for the fluorinated ligands and complexes ( $\left.{ }^{a} \mathrm{CDCl}_{3} ;{ }^{b} \mathrm{CD}_{3} \mathrm{CN}\right)$.

\begin{tabular}{cc} 
Compound & $\delta_{\mathrm{F}} / \mathbf{p p m}$ \\
\hline $\mathrm{L4}^{a}$ & $-130.4(\mathrm{~d}, 21 \mathrm{~Hz}),-131.2(\mathrm{~d}, 21 \mathrm{~Hz})$ \\
$\mathrm{L}^{a}$ & -129.9 \\
{$\left[\operatorname{Ir}(\mathrm{L} 4)_{2}(\text { pic })\right]^{b}$} & $-131.8(\mathrm{~d}, 21 \mathrm{~Hz}),-132.9(\mathrm{~d}, 21 \mathrm{~Hz})$, \\
& $-133.7(\mathrm{~d}, 19 \mathrm{~Hz}),-134.0(\mathrm{~d}, 19 \mathrm{~Hz})$ \\
{$\left[\operatorname{Ir}(\mathrm{L} 7)_{2}(\text { pic })\right]^{b}$} & $-130.2(\mathrm{~d}, 19 \mathrm{~Hz}),-131.5(\mathrm{~d}, 19 \mathrm{~Hz})$, \\
& $-133.1(\mathrm{~d}, 21 \mathrm{~Hz}),-133.6(\mathrm{~d}, 22 \mathrm{~Hz})$ \\
{$\left[\operatorname{Ir}(\mathrm{L} 7)_{2}(\text { pyz })\right]^{a}$} & $-123.5(\mathrm{~d}, 22 \mathrm{~Hz}),-128.1(\mathrm{~d}, 22 \mathrm{~Hz})$, \\
& $-128.5(\mathrm{~d}, 22 \mathrm{~Hz}),-130.5(\mathrm{~d}, 22 \mathrm{~Hz})$ \\
\hline
\end{tabular}

Due to the inequivalence of the cyclometalating ligands, four ${ }^{19} \mathrm{~F}$ resonances, which appear in the -120 to -140 ppm range were observed in the ${ }^{19} \mathrm{~F}\left\{{ }^{1} \mathrm{H}\right\}$ NMR spectra for 
the fluorinated complexes, and thus consistent with the $\left[\operatorname{Ir}(\mathrm{L})_{2}(\right.$ bipy $\left.)\right] \mathrm{PF}_{6}$ analogues. Each resonance appeared as a doublet arising from ${ }^{3} J_{\mathrm{FF}}$ coupling at ca. 19-22 Hz. The ${ }^{19} \mathrm{~F}$ resonances of the picolinate species were subtly shifted upfield from the free ligands, whereas for the pyrazinoate species the resonances were generally downfield. This suggests that the relative donor characteristics of the ancillary ligand can influence the electron density at $\operatorname{Ir}(\mathrm{III})$ and thus modulate the electronic environment of the fluorine substituents on the cyclometalated quinoxaline ligands. The ${ }^{19} \mathrm{~F}\left\{{ }^{1} \mathrm{H}\right\}$ NMR data supports the notion that picolinate is a stronger donor to $\operatorname{Ir}(\mathrm{III})$ than pyrazinoate.

All complexes in this study were also characterized by high resolution mass spectrometry. In each case, a molecular ion peak was present and consistent with the expected isotopic distribution for a protonated parent ion $[\mathrm{M}+\mathrm{H}]^{+}$or a sodium ion adduct, $[\mathrm{M}+\mathrm{Na}]^{+}$. In some cases, a fragment was also present that contained both cyclometalating ligands, but with loss of the ancillary ligand (see Fig. S2, Supporting Information).

\section{X-ray Crystallography Structure}

Single red plate-shaped crystals of $\left[\operatorname{Ir}(\mathrm{L} 7)_{2}\right.$ (pic)] were successfully isolated, from slow evaporation of an acetone solution of the complex, and then investigated using X-ray diffraction. ${ }^{23}$ Data collection parameters are in the caption to Fig. 3; see Table 2 for selected bond lengths and bond angles. The structure reveals that the complex crystallised as its acetone solvate, with one molecule of acetone per complex moiety.

Table 2. Selected bond lengths $(\AA)$ and bond angles $\left({ }^{\circ}\right)$ from the crystallographic data of $\left[\operatorname{lr}(\mathbf{L 7})_{2}(\right.$ pic $\left.)\right]$.

Bond lengths $(\AA)$

\begin{tabular}{llll}
\hline $\operatorname{Ir}(1)-\mathrm{O}(41)$ & $2.156(4)$ & $\operatorname{Ir}(1)-\mathrm{N}(41)$ & $2.195(4)$ \\
$\operatorname{Ir}(1)-\mathrm{N}(1)$ & $2.055(4)$ & $\operatorname{Ir}(1)-\mathrm{C}(1)$ & $1.980(6)$ \\
$\operatorname{Ir}(1)-\mathrm{N}(21)$ & $2.066(4)$ & $\operatorname{Ir}(1)-\mathrm{C}(21)$ & $1.981(6)$ \\
\hline & \multicolumn{3}{c}{ Bond angles $\left(^{\circ}\right)$} \\
\hline $\mathrm{O}(41)-\operatorname{Ir}(1)-\mathrm{N}(41)$ & $76.10(15)$ & $\mathrm{C}(1)-\operatorname{Ir}(1)-\mathrm{N}(21)$ & $96.8(2)$ \\
$\mathrm{N}(1)-\operatorname{Ir}(1)-\mathrm{O}(41)$ & $81.47(15)$ & $\mathrm{C}(1)-\operatorname{Ir}(1)-\mathrm{N}(41)$ & $166.5(2)$ \\
$\mathrm{N}(1)-\operatorname{Ir}(1)-\mathrm{N}(21)$ & $175.58(16)$ & $\mathrm{C}(1)-\operatorname{Ir}(1)-\mathrm{C}(21)$ & $93.3(2)$
\end{tabular}




$$
\begin{array}{llll}
\mathrm{N}(1)-\operatorname{Ir}(1)-\mathrm{N}(41) & 98.55(16) & \mathrm{C}(21)-\operatorname{Ir}(1)-\mathrm{O}(41) & 176.21(16) \\
\mathrm{N}(21)-\operatorname{Ir}(1)-\mathrm{O}(41) & 101.02(15) & \mathrm{C}(21)-\operatorname{Ir}(1)-\mathrm{N}(1) & 98.61(19) \\
\mathrm{N}(21)-\operatorname{Ir}(1)-\mathrm{N}(41) & 85.63(16) & \mathrm{C}(21)-\operatorname{Ir}(1)-\mathrm{N}(21) & 79.15(19) \\
\mathrm{C}(1)-\operatorname{Ir}(1)-\mathrm{O}(41) & 90.41(18) & \mathrm{C}(21)-\operatorname{Ir}(1)-\mathrm{N}(41) & 100.17(19) \\
\mathrm{C}(1)-\operatorname{Ir}(1)-\mathrm{N}(1) & 79.5(2) & &
\end{array}
$$

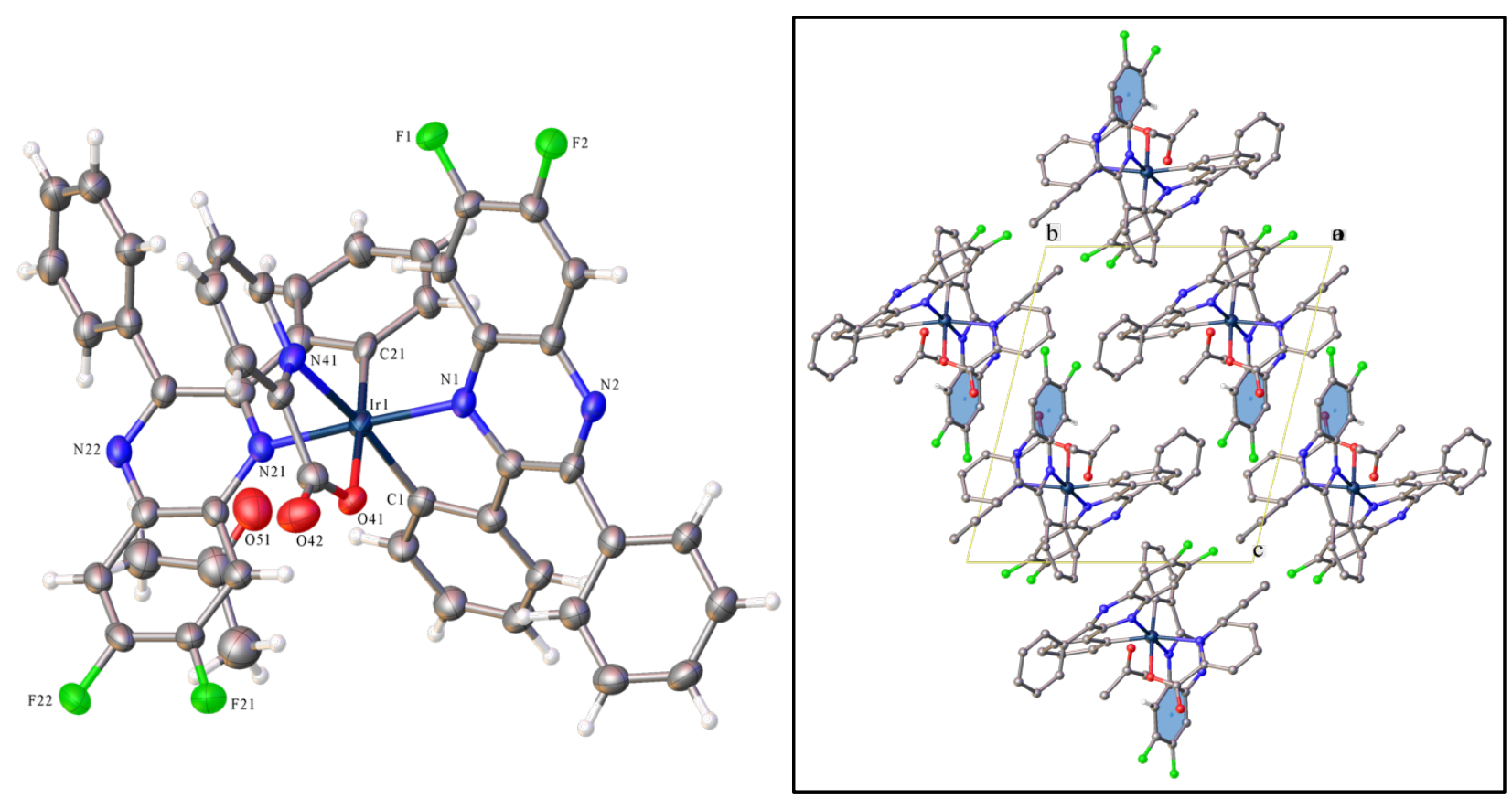

Figure 3. X-ray structure of $\left[\operatorname{lr}(\mathrm{L} 7)_{2}\right.$ (pic)]. $\mathrm{C}_{49} \mathrm{H}_{32} \mathrm{~F}_{4} \mathrm{IrN}_{5} \mathrm{O}_{3}, M_{r}=1006.99$, triclinic, $P-1$ (No. 2), $a=11.4642(3) \AA, b=12.2735(2) \AA, c=14.3213(3) \AA, \alpha=76.139(2)^{\circ}, \beta=$ 86.773(2) $)^{\circ}, \gamma=88.029(2)^{\circ}, V=1952.85(7) \AA^{3}, T=100(2) \mathrm{K}, Z=2, Z^{\prime}=1, \mu\left(\mathrm{CuK}_{\alpha}\right)=$ $7.230 \mathrm{~mm}^{-1}, 51782$ reflections measured, 7115 unique $\left(R_{\text {int }}=0.0887\right)$ which were used in all calculations. The final $w R_{2}$ was 0.1050 (all data) and $R_{1}$ was $0.0411(\mathrm{I}>2(\mathrm{I})$ ). Inset: packing diagram for $\left[\operatorname{lr}(\mathrm{L} 7)_{2}\right.$ (pic)].

The structure confirms the expected coordination sphere at iridium, with the quinoxaline derived ligands coordinating in a cyclometalating mode, resulting in a cis$\mathrm{C}, \mathrm{C}$ and trans-N,N coordination arrangement at $\operatorname{Ir}(\mathrm{III})$. The coordinated picolinate ligand is bound to $\operatorname{Ir}(\mathrm{III})$ via the $\mathrm{N}^{\wedge} \mathrm{O}$ chelating mode. The bond lengths within the coordination sphere are closely comparable to related complexes that incorporate cyclometalated phenyl-quinoxaline ligands. ${ }^{7 b}$ The structure also reveals intermolecular 
packing supported by $\pi-\pi$ interactions of ca. $3.65 \AA$ (see Fig. 3 , inset) that involve the difluorinated quinoxaline ring.

\section{Electrochemical Properties Of The Complexes}

The electrochemical characteristics of the $\operatorname{Ir}(\mathrm{III})$ complexes were investigated in deoxygenated dichloromethane. Cyclic voltammograms were measured using a platinum disc electrode (scan rate $200 \mathrm{mV} \mathrm{s}^{-1}, 1 \times 10^{-3} \mathrm{M}$ solutions, $0.1 \mathrm{M}\left[\mathrm{NBu}_{4}\right]\left[\mathrm{PF}_{6}\right]$ as a supporting electrolyte). In most cases, the complexes each showed one oxidative and one reductive process (Table 3 ). The oxidation process appeared in the range of $+1.1 \mathrm{~V}$ to $+1.4 \mathrm{~V}$ and was attributed, and found to be generally irreversible, to the $\mathrm{Ir}^{3+/ 4+}$ couple. These oxidative values are lower than for the corresponding cationic species $\left[\operatorname{lr}(\mathrm{L})_{2}\right.$ (bipy)]PF 6 which is consistent with an $\mathrm{Ir}^{3+}$ center that is more easily oxidized in these neutral species. Within the series of complexes, the substituents of the quinoxaline cyclometalating ligand have a significant influence upon the redox potentials: the halogenated complexes have higher oxidation potentials, whereas the methylated variants are most easily oxidized. These observations are again consistent with the relative electron donating capacity of the coordinated quinoxaline ligands. The ancillary ligand also has a subtle influence on the $\mathrm{Ir}^{3+/ 4+}$ couple, with the pyrazinoate species possessing a more positive oxidation potential than their picolinate counterparts, again consistent with the relative electron donating capacity of the two ligands. The observed reduction features, most of which were irreversible, are assumed to be ligand-based processes ${ }^{7 b}$ with the pyrazinoate complexes introducing a feature around $-1 \mathrm{~V}$. 
Table 3. UV-vis. absorption and redox properties of the complexes.

\begin{tabular}{|c|c|c|c|}
\hline \multirow[t]{2}{*}{ Complex } & \multirow{2}{*}{$\begin{array}{c}\text { UV-vis. absorption }{ }^{a} \\
\lambda_{\max }(\mathrm{nm})\end{array}$} & \multicolumn{2}{|c|}{ Cyclic voltammetry $^{b}$} \\
\hline & & $E_{\text {ox }}(\mathrm{V})$ & $E_{\text {red }}(\mathrm{V})$ \\
\hline$\left[\operatorname{lr}(\mathrm{L} 1)_{2}(\mathrm{pic})\right]$ & 274 sh, 364 sh, 373,491 sh & +1.16 & -1.42 \\
\hline$\left[\operatorname{lr}(\mathrm{L} 2)_{2}(\mathrm{pic})\right]$ & $276,381,507 \mathrm{sh}$ & +1.11 & -1.51 \\
\hline$\left[\operatorname{lr}(\mathrm{L} 3)_{2}(\mathrm{pic})\right]$ & $273,300,371,389,538 \mathrm{sh}$ & +1.27 & -1.17 \\
\hline$\left[\operatorname{lr}(\mathrm{L} 4)_{2}(\mathrm{pic})\right]$ & $272,361,377,501 \mathrm{sh}$ & +1.26 & $-1.05,-1.27$ \\
\hline$\left[\operatorname{lr}(\mathrm{L} 5)_{2}(\mathrm{pic})\right]$ & $262,300,387,501 \mathrm{sh}$ & +1.09 & -1.25 \\
\hline$\left[\operatorname{lr}(\mathrm{L} 6)_{2}(\mathrm{pic})\right]$ & $273,396,528 \mathrm{sh}$ & +1.31 & -1.12 \\
\hline$\left[\operatorname{lr}(\mathrm{L} 7)_{2}(\mathrm{pic})\right]$ & $277,387,505 \mathrm{sh}$ & +1.30 & -1.24 \\
\hline$\left[\operatorname{lr}(\mathrm{L} 2)_{2}(\mathrm{pyz})\right]$ & $267,380,480 \mathrm{sh}$ & +1.18 & $-0.98,-1.35$ \\
\hline$\left[\operatorname{lr}(\mathrm{L} 5)_{2}(\mathrm{pyz})\right]$ & $271,386,489 \mathrm{sh}$ & +1.19 & $-1.04,-1.42$ \\
\hline$\left[\operatorname{lr}(\mathrm{L} 7)_{2}(\mathrm{pyz})\right]$ & $272,383,494 \mathrm{sh}$ & +1.39 & $-1.00,-1.15$ \\
\hline
\end{tabular}

\section{UV-vis. Absorption Properties Of The Complexes}

The UV-vis. absorption spectra of all complexes were recorded as solutions in chloroform at a concentration of $10^{-5} \mathrm{M}$. Figure 4 shows the spectra recorded for each series. In both sets of spectra, three distinct features can be seen: a peak at around 275-300 nm from ligand-based $\pi-\pi^{*}$ transitions; a feature ca. $375 \mathrm{~nm}$ with a shoulder to around $430 \mathrm{~nm}$, and a broader feature around $500 \mathrm{~nm}$ that tails $>600 \mathrm{~nm}$. In the context of previous reports, both ligand-based $\pi-\pi^{*}$ transitions from the conjugated quinoxalines, and spin allowed MLCT transitions are likely to contribute to the features at $350-450 \mathrm{~nm}$. Similarly, spin forbidden transitions, mediated by the heavy iridium atom, to the ${ }^{3} \mathrm{MLCT}$ state are likely to contribute to the weaker feature (typical $\varepsilon \approx 10^{3}$ $\mathrm{M}^{-1} \mathrm{~cm}^{-1}$ ) that dictate the $500-600 \mathrm{~nm}$ region of the spectra. 

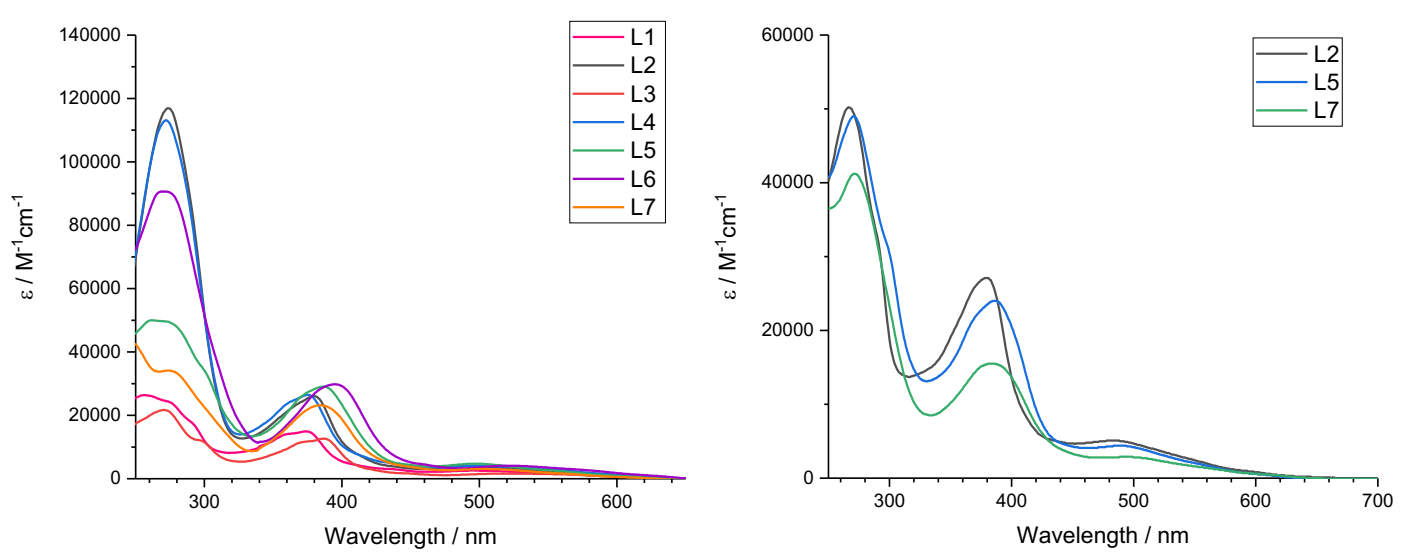

Figure 4. Left: UV-vis. absorption spectra recorded for the picolinate complexes. Right: UVvis. absorption spectra recorded for the pyrazinoate complexes. All samples were recorded in chloroform at $10^{-5} \mathrm{M}$.

Within the series of picolinate complexes, $\left[\operatorname{Ir}(\mathrm{L})_{2}(\right.$ pic $\left.)\right]$, the variations in the energies of the MLCT features are dictated by the nature of the substituents on the quinoxaline ligands. Similarly, the pyrazinoate complexes, $\left[\operatorname{Ir}(L)_{2}(p y z)\right]$, show the same principle features in their absorption spectra. Direct comparison between $\left[\operatorname{Ir}(\mathrm{L} 2)_{2}(\right.$ pic $\left.)\right]$ and $\left[\operatorname{Ir}(\mathrm{L} 2)_{2}(\right.$ pyz)], show that the latter possesses subtly hypsochromically shifted MLCT features. When compared to the previously reported cationic variant $\left[\operatorname{lr}\left(\mathrm{L} 2_{2}\right)_{2}(\right.$ bipy $\left.)\right] P F_{6}$, both neutral analogues display a bathochromically shifted ${ }^{3}$ MLCT feature (Fig. 5 and Figs S3-S8). ${ }^{7 \mathrm{~b}}$

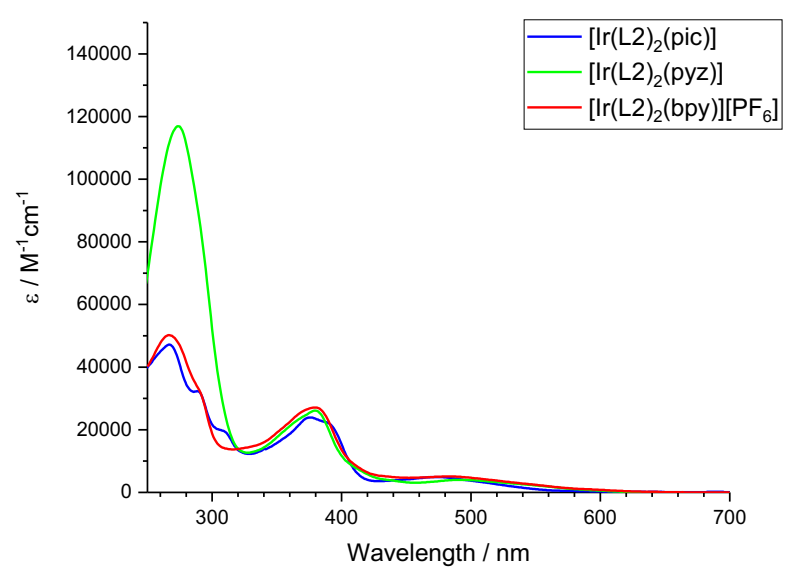

Figure 5. UV-vis. absorption spectra showing the influence of the ancillary ligand (picolinate vs. pyrazinoate vs. bipyridine) across iridium(III) complexes of L2. 


\section{Density Functional Theory (DFT)}

DFT calculations, performed on each complex discussed herein, support the assignments of the features in the absorption spectra through time dependent DFT (TD-DFT). Qualitatively, the simulated absorption spectra (e.g. Fig. 6 and Figs S9S17) are in reasonable agreement with the experimental absorption spectra, each with three main components in the same relative order of intensity as the absorption spectra, although the DFT procedure underestimates the absolute energy of all transitions (Table 4). The absorption bands $<450 \mathrm{~nm}$ are predominantly ${ }^{1} \mathrm{MLCT}$ in character, as the occupied molecular orbitals involved in the excitation generally carry significant metal contributions $(25$ - 38\%), whilst the unoccupied orbitals are predominantly localised on the quinoxaline ligands. The calculations also predict that unoccupied orbitals localised on either the picolinate or pyrazinoate ancillary ligands do not contribute to the LUMO or LUMO+1, but rather dominate LUMO+2 (Tables 4 and 5). The simulated spectra all show a longest wavelength feature 560-620 nm which is predicted to be the spin forbidden ${ }^{3} \mathrm{MLCT}\left(\right.$ i.e. $\mathrm{S}_{0} \rightarrow \mathrm{T}_{1}$ ) transition, which again corresponds to the low intensity shoulder present in the experimentally obtained spectra of the complexes. Comprehensive details for each complex are presented in Supporting Information.
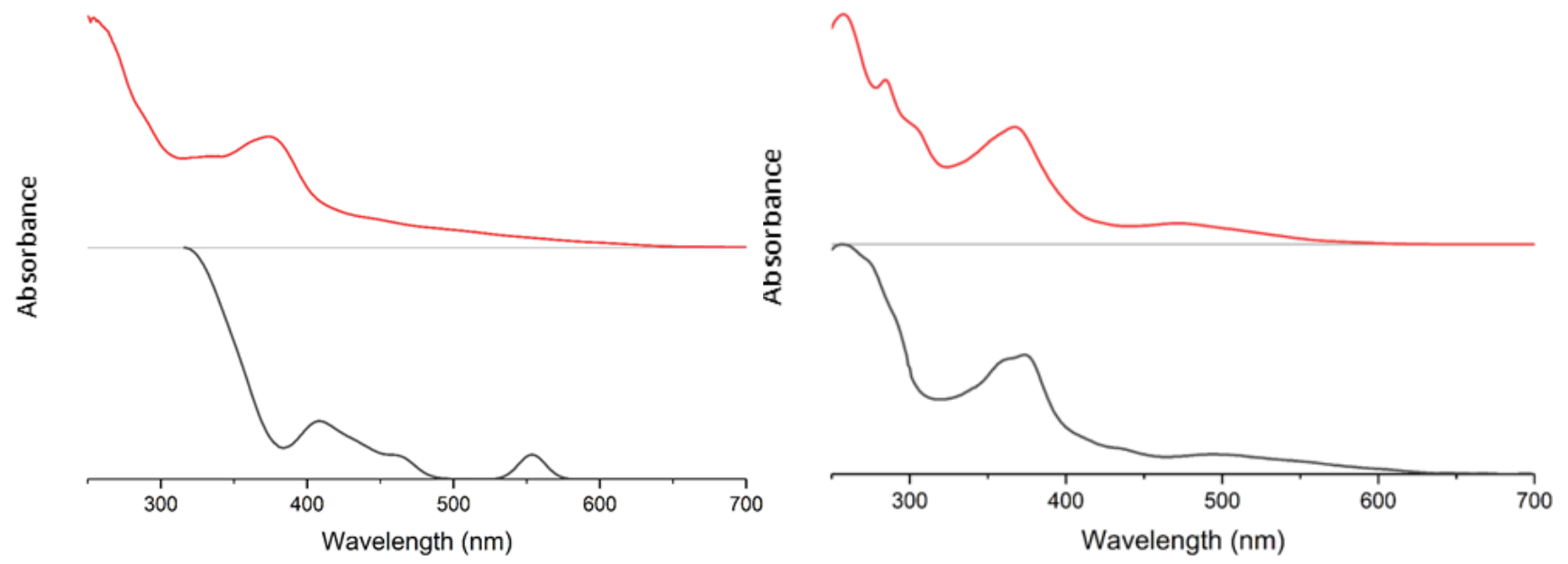

Figure 6. Left: comparison of the experimental (red) and simulated (black) absorption spectra for $\left[\operatorname{Ir}(\mathrm{L} 1)_{2}(\mathrm{pic})\right]$. In the left hand panel, the computed spectrum is constructed by convolution of the TD-DFT transition energies and their associated oscillator strengths. The spin forbidden peak at $\lambda>500 \mathrm{~nm}$ is shown for reference, with an arbitrary oscillator strength scaled as a guide to the eye. The simulated spectrum is comprised of singlet and triplet transitions from 
the singlet ground state. Right: comparison of the observed spectra of $\left[\operatorname{Ir}(\mathrm{L} 1)_{2}(\right.$ pic $\left.)\right]$ (black) and $\left[\operatorname{lr}(\mathrm{L} 1)_{2}(\right.$ bipy $\left.)\right] \mathrm{PF}_{6}($ red).

Table 4. Computed values for the absorption and emission maxima of the $\operatorname{Ir}(\mathrm{III})$ complexes. Experimentally determined $\mathrm{T}_{1} \rightarrow \mathrm{S}_{0}$ values are presented in parentheses.

\begin{tabular}{lccc} 
Complex & $\mathbf{S}_{\mathbf{0}} \rightarrow \mathbf{S}_{\mathbf{1}}(\mathbf{n m})$ & $\mathbf{S}_{\mathbf{0}} \rightarrow \mathbf{T}_{\mathbf{1}}(\mathbf{n m})$ & $\mathbf{T}_{\mathbf{1}} \rightarrow \mathbf{S}_{\mathbf{0}}(\mathbf{n m})$ \\
\hline$\left[\operatorname{Ir}(\mathrm{L} 1)_{2}(\right.$ pic $\left.)\right]$ & 424 & 578 & $697(646)$ \\
{$\left[\operatorname{Ir}(\mathrm{L} 2)_{2}(\right.$ pic $\left.)\right]$} & 419 & 568 & $689(640)$ \\
{$\left[\operatorname{Ir}(\mathrm{L} 3)_{2}(\right.$ pic $\left.)\right]$} & 440 & 608 & $739(667)$ \\
{$\left[\operatorname{Ir}(\mathrm{L} 4)_{2}(\right.$ pic $\left.)\right]$} & 428 & 586 & $710(651)$ \\
{$\left[\operatorname{Ir}(\mathrm{L} 5)_{2}(\right.$ pic $\left.)\right]$} & 425 & 579 & $705(648)$ \\
{$\left[\operatorname{Ir}(\mathrm{L} 6)_{2}(\right.$ pic $\left.)\right]$} & 445 & 618 & $751(675)$ \\
{$\left[\operatorname{Ir}(\mathrm{L} 7)_{2}(\right.$ pic $\left.)\right]$} & 434 & 597 & $722(659)$ \\
{$\left[\operatorname{Ir}(\mathrm{L} 2)_{2}(\right.$ pyz $\left.)\right]$} & 416 & 563 & $685(632)$ \\
{$\left[\operatorname{Ir}(\mathrm{L} 5)_{2}(\right.$ pyz $\left.)\right]$} & 422 & 573 & $703(641)$ \\
{$\left[\operatorname{Ir}(\mathrm{L} 7)_{2}(\right.$ pyz $\left.)\right]$} & 431 & 589 & $714(651)$ \\
\hline
\end{tabular}

Table 5. A summary of the major calculated contributions to each MO from each part of the complex. Q1 and Q2 are the inequivalent quinoxaline ligands.

\begin{tabular}{|c|c|c|c|c|c|c|c|}
\hline \multirow[b]{2}{*}{ Complex } & \multicolumn{2}{|c|}{$\operatorname{Ir} 5 d$} & \multicolumn{2}{|c|}{ Q1 } & \multicolumn{2}{|c|}{ Q2 } & \multirow{2}{*}{$\begin{array}{l}\text { pic/pyz } \\
\text { LUMO+2 }\end{array}$} \\
\hline & HOMO-1 & HOMO & LUMO & LUMO+1 & LUMO & LUMO+1 & \\
\hline$\left[\operatorname{lr}(\mathrm{L} 1)_{2}(\mathrm{pic})\right]$ & 43 & 40 & 36 & 59 & 59 & 36 & 96 \\
\hline$\left[\operatorname{lr}(\mathrm{L} 2)_{2}(\mathrm{pic})\right]$ & 37 & 39 & 34 & 60 & 60 & 34 & 96 \\
\hline$\left[\operatorname{lr}(\mathrm{L} 3)_{2}(\mathrm{pic})\right]$ & 41 & 39 & 40 & 55 & 55 & 40 & 94 \\
\hline$\left[\operatorname{lr}(\mathrm{L} 4)_{2}(\mathrm{pic})\right]$ & 40 & 39 & 39 & 56 & 56 & 39 & 96 \\
\hline$\left[\operatorname{lr}(\mathrm{L} 5)_{2}(\mathrm{pic})\right]$ & 21 & 38 & 38 & 57 & 57 & 38 & 94 \\
\hline$\left[\operatorname{lr}(\mathrm{L} 6)_{2}(\mathrm{pic})\right]$ & 21 & 38 & 42 & 53 & 53 & 41 & 6 \\
\hline$\left[\operatorname{lr}(\mathrm{L} 7)_{2}(\mathrm{pic})\right]$ & 16 & 38 & 41 & 54 & 54 & 41 & 90 \\
\hline$\left[\operatorname{lr}(\mathrm{L} 2)_{2}(\mathrm{pyz})\right]$ & 28 & 38 & 48 & 47 & 38 & 39 & 77 \\
\hline$\left[\operatorname{lr}(\mathrm{L} 5)_{2}(\mathrm{pyz})\right]$ & 10 & 37 & 41 & 35 & 47 & 48 & 76 \\
\hline$\left[\operatorname{lr}(\mathrm{L} 7)_{2}(\mathrm{pyz})\right]$ & 8 & 37 & 44 & 46 & 49 & 46 & 89 \\
\hline
\end{tabular}


Again, it is useful to compare these systems against their cationic complex analogues, $\left[\operatorname{lr}(\mathrm{L})_{2}(\right.$ bipy $\left.)\right] \mathrm{PF}_{6}{ }^{7 b}{ }^{\text {In }}$ In those systems, the complexes exhibited $C_{2}$ symmetry and the two coordinated quinoxaline ligands were effectively degenerate, with equal contributions from each to the frontier orbitals, suggesting significant delocalization. Moving from a bipyridine ancillary ligand to the picolinate/pyrazinoate complexes reported herein removes this delocalization, breaking the symmetry of the system and splitting the orbital contributions of the quinoxalines.

The molecular orbitals within the picolinate complexes (Fig. 7 and Figs S18S23) now form pseudo-degenerate pairs with alternating contributions from each of the quinoxalines: e.g. the $\left[\operatorname{lr}(\mathrm{L} 1)_{2}(\mathrm{pic})\right] \mathrm{LUMO}$ is made up of contributions of $36 \%$ and $59 \%$ (Table 6) from the quinoxalines, Q1 and Q2 respectively, whilst the LUMO+1 shows the reverse $(\mathrm{Q} 1=59 \%$; $\mathrm{Q} 2=36 \%$ ). This effect is presumably due to the differing interactions of the two quinoxalines with the asymmetric ancillary ligand. Notably, the pyrazinoate complexes do not show these pseudo-degenerate pairs, but nonetheless show a loss of degeneracy between the quinoxaline ligands, with greater contributions from one quinoxaline than the other. This effect likely contributes to the weak structure observed in the experimental absorption spectra between $300 \mathrm{~nm}<\lambda$ $<400 \mathrm{~nm}$. The TD-DFT calculations also suggest that there are no singlet transitions (Table 6) at wavelengths long enough to account for the absorption at $\lambda>500 \mathrm{~nm}$, whereas the lowest energy singlet-to-triplet transition is within the $550 \mathrm{~nm}<\lambda<620$ $\mathrm{nm}$ region for all complexes. This is consistent with the observation of the long wavelength, low intensity absorption shoulder band observed in the experimental data (Fig. 6). Supporting Information contains the molecular orbital decomposition analysis for $\left[\operatorname{lr}(\mathrm{L})_{2}(\mathrm{pic})\right](\mathrm{L}=\mathrm{L} 2-\mathrm{L} 7)$ and $\left[\operatorname{Ir}(\mathrm{L})_{2}(\mathrm{pyz})\right](\mathrm{L}=\mathrm{L} 2$, L5 and L7) (Figs S18-S26, and Tables S1-9). 
Table 6. A description of the calculated MO contributions, excited state descriptions and their associated transitions for $\left[\operatorname{Ir}(\mathrm{L} 1)_{2}(\mathrm{pic})\right](\mathrm{Q} 1$ and $\mathrm{Q} 2$ are the different quinoxaline ligands; pic $=$ picolinate) .

\begin{tabular}{|c|c|c|c|c|c|c|}
\hline$\left[\operatorname{lr}(\mathbf{L} 1)_{2}(\mathbf{p i c})\right]$ & \multicolumn{4}{|c|}{$\begin{array}{c}\text { Moiety Contributions to } \\
\text { Orbital (\%) }\end{array}$} & \multicolumn{2}{|c|}{ Orbital Contributions to Excited States } \\
\hline Orbital & $\begin{array}{c}I r \\
(5 d)\end{array}$ & Pic & Q1 & Q2 & Excited State & Contributing Transitions \\
\hline $\begin{array}{l}\text { LUMO+4 } \\
\text { LUMO+3 }\end{array}$ & $\begin{array}{l}1 \\
1\end{array}$ & $\begin{array}{c}1 \\
23\end{array}$ & $\begin{array}{l}78 \\
15\end{array}$ & $\begin{array}{l}21 \\
62\end{array}$ & $\begin{array}{l}1(423.97 \mathrm{~nm}, \mathrm{f}=0.0349) \\
2(415 \mathrm{~nm}, \mathrm{f}=0.1237)\end{array}$ & $\begin{array}{l}\text { HOMO } \rightarrow \text { LUMO }(87 \%) \\
\text { HOMO } \rightarrow \text { LUMO+1 }(84 \%)\end{array}$ \\
\hline LUMO+2 & 2 & 96 & 2 & 0 & & \\
\hline LUMO+1 & 4 & 1 & 59 & 36 & $3(343.01 \mathrm{~nm}, \mathrm{f}=0.089)$ & HOMO-2 $\rightarrow$ LUMO (37\%) \\
\hline LUMO & 4 & 1 & 36 & 59 & & $\rightarrow$ LUMO (43\%) \\
\hline номо & 40 & 4 & 29 & 27 & $4(329.34 \mathrm{~nm}, \mathrm{f}=0.0442)$ & HOMO-1 $\rightarrow$ LUMO+1 (21\%) \\
\hline HOMO-1 & 43 & 14 & 23 & 20 & & \\
\hline HOMO-2 & 9 & 8 & 51 & 32 & $5(321.19 \mathrm{~nm}, \mathrm{f}=0.1511)$ & HOMO-3 $\rightarrow$ LUMO (38\%) \\
\hline HOMO-3 & 34 & 5 & 14 & 47 & & \\
\hline HOMO-4 & 14 & 19 & 54 & 13 & & \\
\hline
\end{tabular}

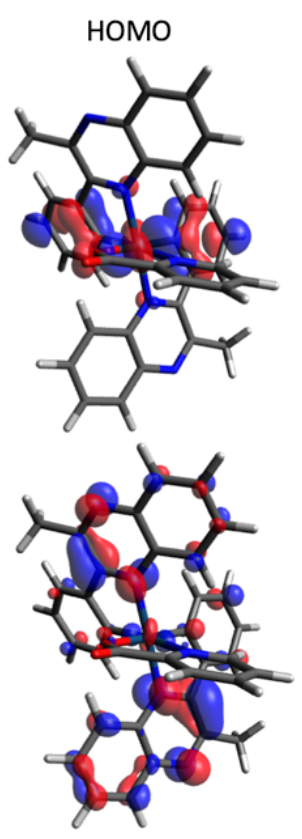

LUMO
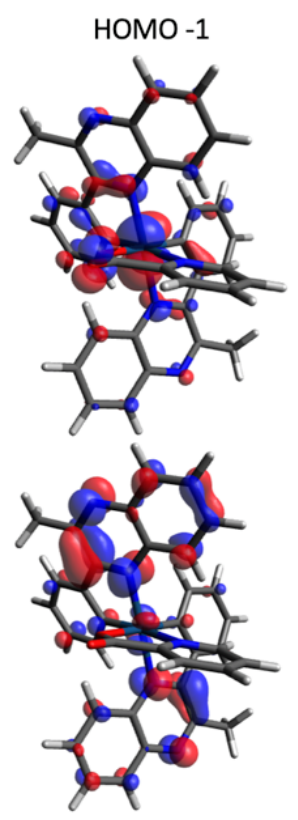

LUMO +1
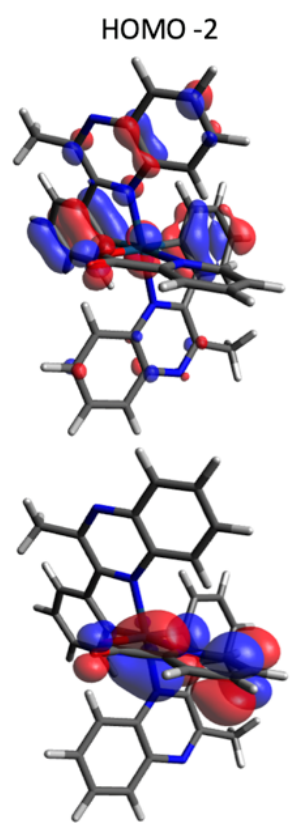

$\mathrm{LUMO}+2$
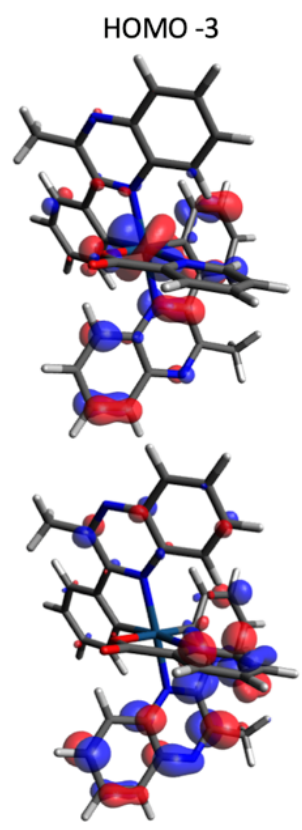

$\mathrm{LUMO}+3$
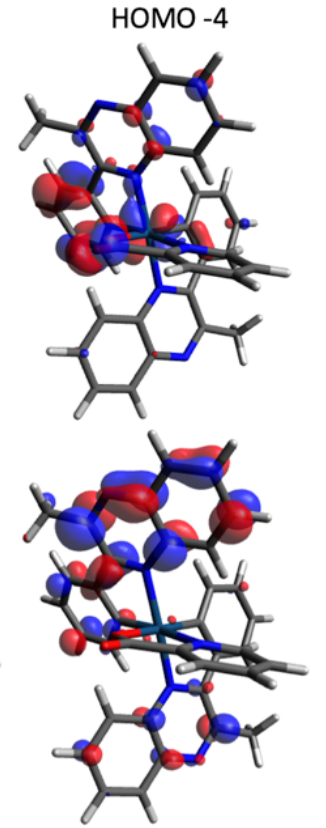

LUMO +4

Figure 7. Examples of calculated Kohn-Sham molecular orbitals for $\left[\operatorname{lr}(\mathrm{L} 1)_{2}(\right.$ pic $\left.)\right]$. Similar representations for all other complexes in the series are available in Supporting Information. 
Singlet and triplet geometries were calculated for each of the complexes along with stationary point energy estimations of each spin state from the others geometry allowing vertical transitions to be calculated. This was performed with the goal of simulating the spin-forbidden absorption and emission bands using approximations of the purely electronic component of the transition, without the geometric energy contributions associated with changing between the two different spin states. However, the calculated spin-forbidden absorption and emission bands significantly underestimate the energies involved; for example, the emission maximum for $\left[\operatorname{lr}(\mathrm{L} 2)_{2}(\right.$ pic) $]$ is experimentally observed at $640 \mathrm{~nm}$ (see later discussion), yet the calculated $T_{1} \rightarrow S_{0}$ vertical transition value was $689 \mathrm{~nm}$. Therefore this method can be considered as giving a good qualitative rather than quantitative insight into the effect that ligand structure alterations will have upon the complex's spectral properties, as the ordering of the complex emission centers is correct, despite the energetic offset.

The predicted effects of quinoxaline ligand substitution were investigated by examining the energy values of the HOMO and LUMO for each of the complexes (Table 7). Electron withdrawing groups are known to have a stabilising effect upon the metal-dominated HOMO through the removal of electron density, whilst electron donating groups have the inverse effect. ${ }^{24}$ Here, those complexes possessing quinoxaline ligands with electron withdrawing groups (e.g. $\mathrm{F}, \mathrm{Cl}$ ) exhibit lower energy values for the frontier orbitals. The LUMO is typically stabilised more effectively than the HOMO, a feature that can be ascribed to the greater involvement of the quinoxaline ligands in the LUMO and thus a more pronounced effect as the electron affinity of the ligand is increased. This disparity between the effect on each orbital gives rise to the slight differences in emission and absorption energies observed for the complexes, as the HOMO to LUMO gap is reduced for those with electron withdrawing groups and increased for those with electron donating groups (e.g. Me), relative to the unsubstituted complex $\left[\operatorname{lr}(\mathrm{L} 1)_{2}(\mathrm{pic})\right]$. The phenyl substituted complexes exhibit very similar HOMO energy values to their methylated counterparts, but show lower LUMO values. 
Table 7. Calculated energies of the frontier orbitals of the iridium(III) complexes and their differences, ordered by decreasing $\Delta \mathrm{E}$.

\begin{tabular}{|c|c|c|c|}
\hline Complex & HOMO $(\mathrm{eV})$ & LUMO (eV) & $\Delta E(e V)$ \\
\hline$\left[\mathrm{Ir}(\mathrm{L} 2)_{2}(\mathrm{pyz})\right]$ & -5.43 & -2.41 & 3.02 \\
\hline$\left[\operatorname{lr}(\mathrm{L} 2)_{2}(\mathrm{pic})\right]$ & -5.33 & -2.32 & 3.01 \\
\hline$\left[\operatorname{lr}(\mathrm{L} 5)_{2}(\mathrm{pyz})\right]$ & -5.44 & -2.46 & 2.98 \\
\hline$\left[\operatorname{lr}(\mathrm{L} 1)_{2}(\mathrm{pic})\right]$ & -5.42 & -2.45 & 2.97 \\
\hline$\left[\operatorname{lr}(\mathrm{L} 5)_{2}(\mathrm{pic})\right]$ & -5.34 & -2.38 & 2.96 \\
\hline$\left[\mathrm{I} r(\mathrm{~L} 7)_{2}(\mathrm{pyz})\right]$ & -5.63 & -2.73 & 2.9 \\
\hline$\left[\operatorname{lr}(\mathrm{L} 4)_{2}(\mathrm{pic})\right]$ & -5.53 & -2.6 & 2.93 \\
\hline$\left[\operatorname{lr}(\mathrm{L} 7)_{2}(\mathrm{pic})\right]$ & -5.53 & -2.65 & 2.88 \\
\hline$\left[\operatorname{lr}(\mathrm{L} 3)_{2}(\mathrm{pic})\right]$ & -5.6 & -2.75 & 2.85 \\
\hline$\left[\operatorname{lr}(\mathrm{L} 6)_{2}(\mathrm{pic})\right]$ & -5.61 & -2.79 & 2.82 \\
\hline
\end{tabular}

The effect of the ancillary ligand is somewhat similar: varying the ligand stabilises or destabilises the frontier orbitals of the complex by removing or increasing electron density on the metal center. In this case, both ligand types (picolinate and pyrazinoate) are relatively electron withdrawing, and the effect is more pronounced for the pyrazinoates due to the presence of an additional nitrogen in the ring. Although the electron withdrawal stabilises the HOMO and LUMO, the relative stabilisation is not identical to the effect of quinoxaline substitution. In this instance, the calculated energies of the MOs suggest the pyrazinoate complexes have HOMO $(0.1 \mathrm{eV})$ levels which are stabilised slightly more than the LUMO $(\sim 0.09 \mathrm{eV})$, when compared to their picolinate counterparts. This effect gives rise to a predicted slight hypsochromic shift in the pyrazinoate complexes. The changes in HOMO vs. LUMO stabilisation may be readily explained by the larger metal contribution to the HOMO. It is worth noting that the similarity in band profile of the emission spectra regardless of ancillary ligand, along with the almost identical nature of the long wavelength ${ }^{1} \mathrm{MLCT}$ absorption bands displayed in Figure 5, illustrate that although the ancillary ligand may tune the position of the HOMO and LUMO orbitals, it does not significantly contribute to them, nor change the overall electronic character. This is consistent with the orbital decomposition analysis presented above.

\section{Luminescence Properties Of The Complexes}

Emission spectra were obtained on each of the complexes using aerated chloroform and an excitation wavelength of $355 \mathrm{~nm}$ (Fig. 8). Each of the neutral complexes were emissive in the red region of the spectrum between $632-675 \mathrm{~nm}$, with quantum yields 
$(\phi)$ typically ca. $5 \%$ (Table 8). All emission peaks appear as featureless broad bands. Observed emission lifetimes ( $\tau_{\text {obs }}$ ) were obtained from time-resolved data fitted to a mono-expenential function. Values for the rates of non-radiative $\left(k_{\mathrm{nr}}\right)$ and radiative $\left(k_{\mathrm{r}}\right)$ decays were calculated from the experimental data and show that $k_{\mathrm{nr}}>>k_{\mathrm{r}}$ in all cases. The $k_{r}$ values are indicative of a significant SOC contribution, but slightly lower than that reported for fac-[Ir(ppy) $\left.)_{3}\right] 4 \times 10^{5} \mathrm{~s}^{-1} .^{25}$

Table 8. Experimentally determined photophysical properties of the complexes. ${ }^{a}$

\begin{tabular}{lccccc} 
Complex & $\lambda_{\mathrm{em}}(\mathbf{n m})^{b}$ & $\tau_{\text {obs }}(\mathbf{n s})^{c}$ & $\phi(\%)^{d}$ & $\boldsymbol{k}_{\mathrm{nr}}\left(\times \mathbf{1 0}^{6}\right)$ & $\boldsymbol{k}_{\mathbf{r}}\left(\times \mathbf{1 0}^{5}\right)$ \\
\hline$\left[\operatorname{Ir}(\mathrm{L} 1)_{2}(\right.$ pic $\left.)\right]$ & 647 & $303.9 \pm 0.1$ & 4.1 & 3.2 & 1.3 \\
{$\left[\operatorname{Ir}(\mathrm{L} 2)_{2}(\right.$ pic $\left.)\right]$} & 640 & $285.6 \pm 0.5$ & 6.8 & 3.3 & 2.4 \\
{$\left[\operatorname{Ir}(\mathrm{L} 3)_{2}(\right.$ pic $\left.)\right]$} & 665 & $266.3 \pm 0.1$ & 3.6 & 3.6 & 1.4 \\
{$\left[\operatorname{Ir}(\mathrm{L} 4)_{2}(\right.$ pic $\left.)\right]$} & 650 & $289 \pm 0.1$ & 4.8 & 3.3 & 1.7 \\
{$\left[\operatorname{Ir}(\mathrm{L} 5)_{2}(\right.$ pic $\left.)\right]$} & 648 & $306.0 \pm 0.2$ & 3.2 & 3.1 & 1.0 \\
{$\left[\operatorname{Ir}(\mathrm{L} 6)_{2}(\right.$ pic $\left.)\right]$} & 680 & $285.0 \pm 0.5$ & 2.7 & 3.4 & 0.9 \\
{$\left[\operatorname{Ir}(\mathrm{L} 7)_{2}(\right.$ pic $\left.)\right]$} & 653 & $290.4 \pm 0.1$ & 4.8 & 3.3 & 1.7 \\
{$\left[\operatorname{Ir}(\mathrm{L} 2)_{2}(\mathrm{pyz})\right]$} & 633 & $351.0 \pm 0.9$ & 5.9 & 2.7 & 1.7 \\
{$\left[\operatorname{Ir}(\mathrm{L} 5)_{2}(\mathrm{pyz})\right]$} & 641 & $328.2 \pm 0.1$ & 2.9 & 3.0 & 0.9 \\
{$\left[\operatorname{Ir}(\mathrm{L} 7)_{2}(\mathrm{pyz})\right]$} & 651 & $352.0 \pm 0.1$ & 1.3 & 2.8 & 0.4 \\
\hline
\end{tabular}

${ }^{a}$ aerated chloroform solutions; ${ }^{b}$ emission wavelength, $\lambda_{\mathrm{exc}}=355 \mathrm{~nm} ;{ }^{\mathrm{c}}$ observed lifetime; ${ }^{\mathrm{d}}$ quantum yield. 

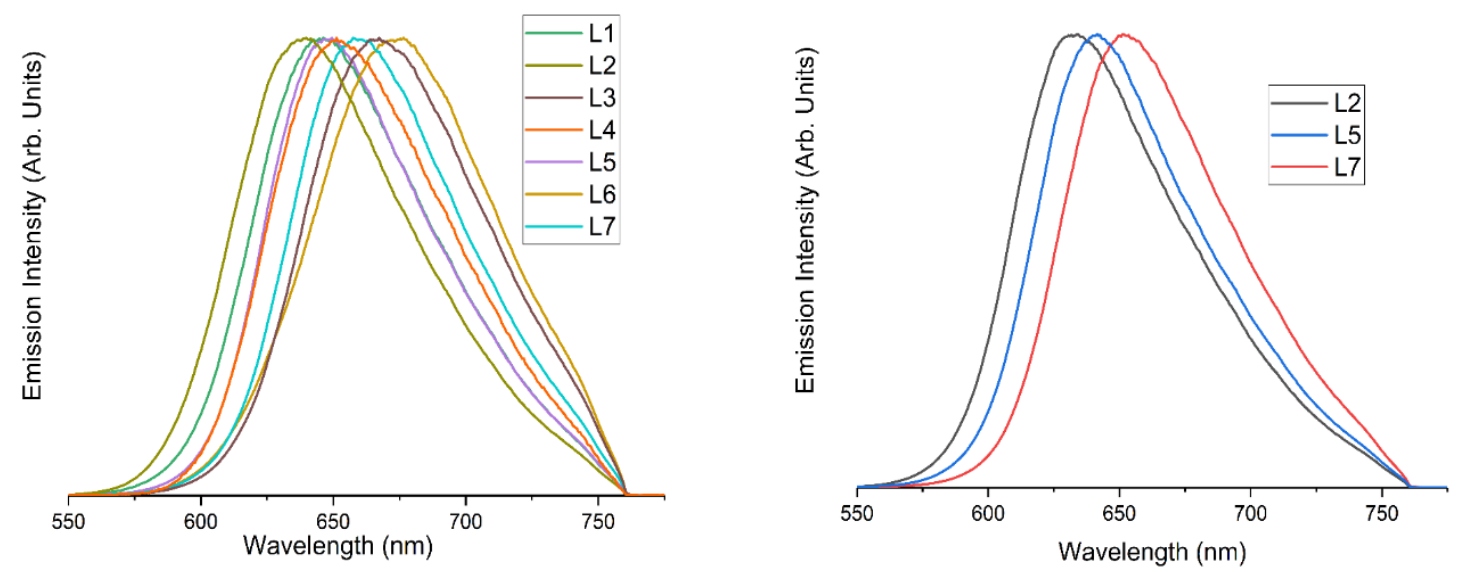

Figure 8. Emission spectra obtained for the picolinate complexes, $\left[\operatorname{Ir}(\mathrm{L})_{2}(\right.$ pic $\left.)\right]$, shown left; and pyrazinoate complexes, $\left[\operatorname{Ir}(\mathrm{L})_{2}(\mathrm{pyz})\right]$, shown right.

When compared to the corresponding cationic complexes, $\left[\operatorname{Ir}(L)_{2}(\right.$ bipy $\left.)\right] P F_{6}$, the current series of compounds demonstrate bathochromically shifted emission maxima for a given quinoxaline ligand (Fig. 8). As noted earlier, the trend across the series of complexes in the experimental emission maxima is quite well replicated using the computational methods discussed earlier. For example, $\left[\operatorname{lr}(\mathrm{L} 2)_{2}(\mathrm{pyz})\right]$, which was calculated to possess the largest HOMO-LUMO energy gap, also displayed the shortest wavelength emission band. A comparison of the emission data for $\left[\operatorname{lr}(\mathrm{L} 2)_{2}(\mathrm{pic})\right]$ and $\left[\operatorname{Ir}(\mathrm{L} 2)_{2}(\mathrm{pyz})\right]$ shows that the latter is indeed hypsochromically shifted. However, the cyclic voltammetry data showed that $\left[\operatorname{lr}(\mathrm{L} 2)_{2}(\mathrm{pyz})\right]$ possesses the smallest electrochemical band gap in the series of complexes. For a pure ${ }^{3} \mathrm{MLCT}$ emitter, the decrease in electrochemical band gap would be expected to manifest in a bathochromic shift in $\lambda_{\mathrm{em}}{ }^{26}$

In the cases of $\left[\operatorname{lr}(\mathrm{L} 2)_{2}(\mathrm{pic})\right]$ and $\left[\operatorname{lr}(\mathrm{L} 2)_{2}(\mathrm{pyz})\right]$, additional deoxygenated luminescence lifetimes show modest increases to 1.283 and $1.883 \mu \mathrm{s}$, respectively. The magnitude of these lifetimes are consistent with the reduction in ${ }^{3} \mathrm{O}_{2}$ collisional quenching, affording definitive assignment that the emissive state is triplet in character. A comparison of the $77 \mathrm{~K}$ emission spectra (Fig. S27) for $\left[\operatorname{lr}(\mathrm{L} 2)_{2}(\mathrm{pic})\right]$ and $\left[\operatorname{lr}(\mathrm{L} 2)_{2}\right.$ (pyz)] (as 1:3 MeOH/EtOH frozen glasses) show emission profiles with a little vibronic definition and a slight hypsochromic shift to $\lambda_{\mathrm{em}}=627 \mathrm{~nm}$ and $617 \mathrm{~nm}$ respectively, which can be attributed to the rigidochromic effect of the frozen medium. 
Further, solvatochromic luminescence studies were conducted on $\left[\operatorname{lr}(\mathrm{L} 2)_{2}(\mathrm{pyz})\right]$ using a range of different solvents. The resultant data in toluene $\left(\lambda_{\mathrm{em}}=622 \mathrm{~nm}\right)$, dichloromethane $(626 \mathrm{~nm})$, acetonitrile $(632 \mathrm{~nm})$ and dimethylsulfoxide $(636 \mathrm{~nm})$ show a subtle bathochromic shift upon increasing solvent polarity. Taken together these observations suggest that some ${ }^{3} \mathrm{MLCT}$ character is likely to contribute to the emitting state of these complexes as implied by the supporting DFT calculations.

\section{Transient Absorption Spectra and Kinetics}

Transient absorption (TA) spectra of the $\operatorname{Ir}(\mathrm{III})$ complexes showed three distinct features (Fig. 9 and Figs, S28-S36). The first, ca. $350<\lambda<400 \mathrm{~nm}$, is ascribed to a ground state bleach: the depletion of the ground state ${ }^{1} \mathrm{MLCT}$ absorption band was seen in this region for all complexes. The second TA band is a strong positive going feature in the $400 \mathrm{~nm}<\lambda<500 \mathrm{~nm}$ region, with two peaks discernible in most of the spectra. These are assigned as triplet-to-triplet transitions as the lifetimes (Table 8) of the features correspond closely to those of the $T_{1} \rightarrow S_{0}$ emission decay kinetics of the complexes (Fig. 9 and Figs S37-S45). Assignments of these features as photophysics arising from triplet state manifolds were confirmed by the extension of all observed transient lifetimes in the absence of oxygen (using $\left[\operatorname{lr}(\mathrm{L} 2)_{2}(\mathrm{pic})\right]$ and $\left[\operatorname{lr}(\mathrm{L} 2)_{2}(\mathrm{pyz})\right]$ as exemplars), consistent with rapid intersystem crossing occurring within the instrument response function (sub-nanosecond) (Table 9). 

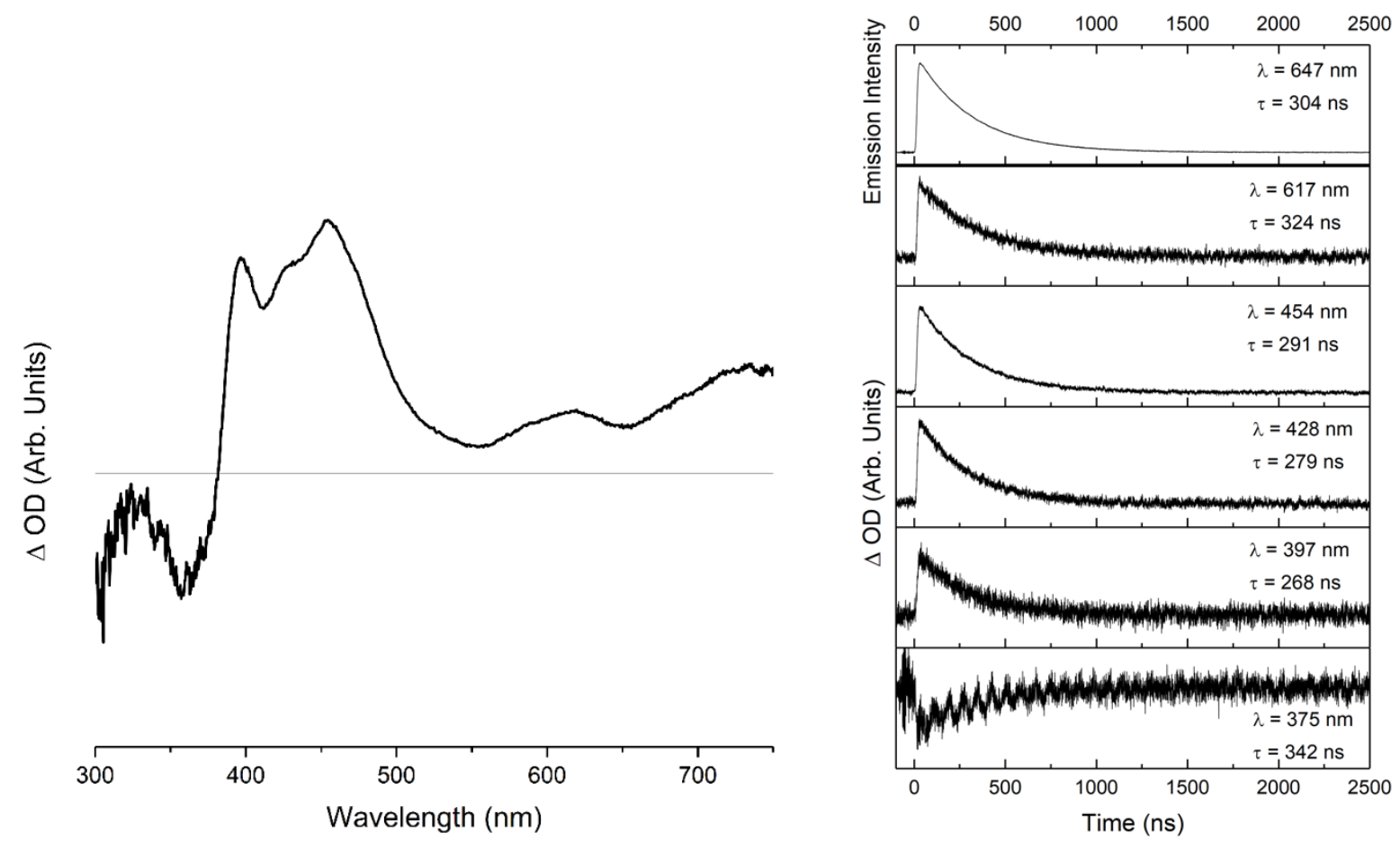

Figure 9. Left: Example of a transient absorption spectrum using $\left[\operatorname{Ir}(\mathrm{L} 1)_{2}(\mathrm{pic})\right]$. The grey horizontal line corresponds to a $\triangle \mathrm{OD}$ value of zero, such that negative trajectory features correspond to depletion of a ground state absorption and positive features corresponding to excited state absorption. Right: The kinetic traces of the major features of $\left[\operatorname{lr}(\mathrm{L} 1)_{2}(\mathrm{pic})\right]$. The top trace is an emission trace, the bottom five are difference of optical density measurements. All traces are fitted to mono-exponential functions and the obtained lifetimes are displayed alongside. Similar representations for all other complexes in the series are available in Supporting Information.

TD-DFT calculations, performed at the triplet state minimum energy geometry, are also in agreement with this assignment, suggesting that there are a set of spin-allowed transitions within this wavelength region. Also visible in the TA spectra is a broad, but weak, positive going signal, centered ca. $\lambda=600 \mathrm{~nm}$. This was also assigned to a triplet-to-triplet absorption. 

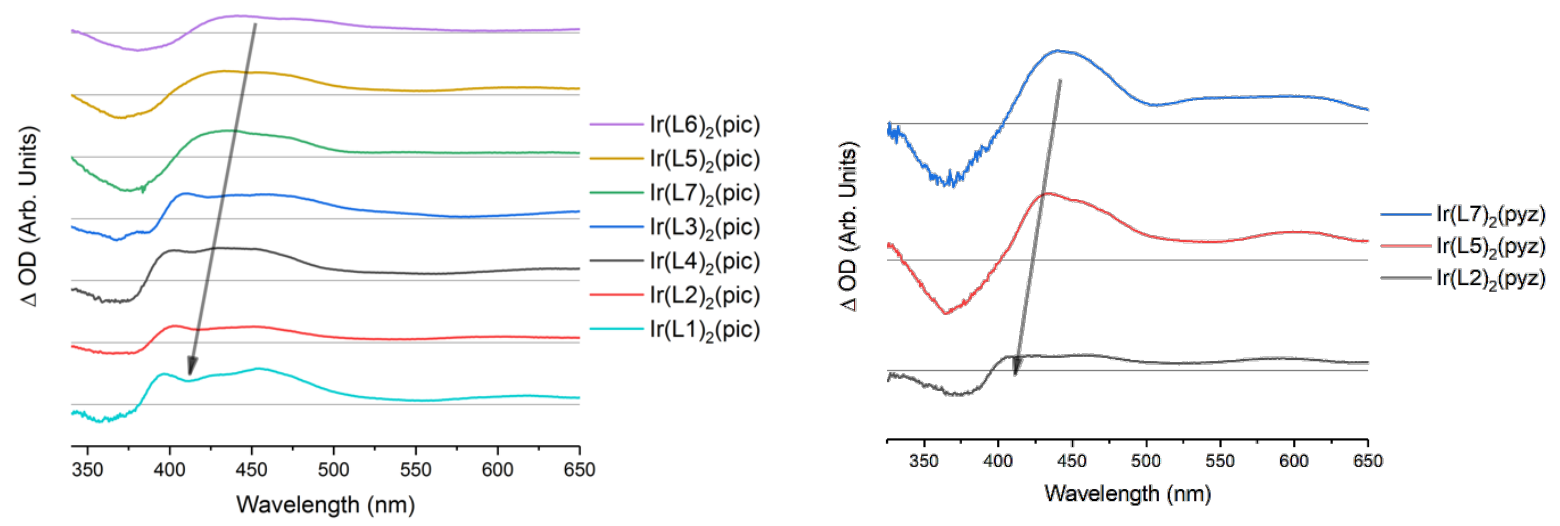

Figure 10. Comparison of the TA spectra of the picolinate (left) and pyrazinoate (right) $\operatorname{Ir}(\mathrm{III})$ complexes. The grey arrows highlight the spectral shifts described in the main text.

The structured absorption profiles in the region $400 \mathrm{~nm}<\lambda<500 \mathrm{~nm}$ (notably in Fig. 9) are ascribed to the pseudo-degeneracy of the LUMO noted in the DFT section, resulting in numerous absorption features very close to each other in energy. This can be observed faintly in the ground state absorption spectra of some of the complexes, but is far more prominent in the TA spectra, highlighting the sensitivity of this technique as a means of characterisation. Importantly, this structure to the absorption feature was not visible in the cationic variants, $\left[\operatorname{Ir}(\mathrm{L})_{2}(\mathrm{bipy})\right] \mathrm{PF}_{6} .{ }^{7 \mathrm{~b}}$ As with the emission spectra, the TA spectra display a band shift (Fig. 10) relative to $\left[\operatorname{Ir}(\mathrm{L} 1)_{2}(\right.$ pic) $]$ depending on the ligand type. All of the picolinate complexes exhibit TA spectra that are bathochromically shifted relative to the $\left[\operatorname{Ir}(\mathrm{L} 1)_{2}(\mathrm{pic})\right]$ complex. The magnitude of this shift depends on the quinoxaline ligand substitution, with phenyl substituted ligands inducing a greater shift than simple halogenation at the quinoxaline ring (Table 9). It is noteworthy, that very few examples of the TA spectra of organometallic complexes have been reported in the literature. ${ }^{27}$ 
Table 9. Time-resolved transient absorption properties of the complexes.

\begin{tabular}{|c|c|c|}
\hline Complex & Ground State Bleach & Excited State Absorption \\
\hline$\left[\operatorname{lr}(\mathrm{L} 1)_{2}(\mathrm{pic})\right]^{\mathrm{a}}$ & 375 nm (341.9 \pm 7.9 ns) & $\begin{array}{l}397 \mathrm{~nm}(268.4 \pm 3.0 \mathrm{~ns}) \\
428 \mathrm{~nm}(279.3 \pm 1.1 \mathrm{~ns}) \\
454 \mathrm{~nm}(290.8 \pm 0.5 \mathrm{~ns}) \\
617 \mathrm{~nm}(324.2 \pm 1.7 \mathrm{~ns})\end{array}$ \\
\hline$\left[\operatorname{lr}(\mathrm{L} 2)_{2}(\mathrm{pic})\right]^{\mathrm{a}}$ & $375 \mathrm{~nm}(332.3 \pm 5.8 \mathrm{~ns})$ & $\begin{array}{l}400 \mathrm{~nm}(304.6 \pm 4.8 \mathrm{~ns}) \\
410 \mathrm{~nm}(301.5 \pm 2.0 \mathrm{~ns}) \\
460 \mathrm{~nm}(320.9 \pm 2.2 \mathrm{~ns}) \\
600 \mathrm{~nm}(350.0 \pm 2.0 \mathrm{~ns})\end{array}$ \\
\hline$\left[\operatorname{lr}(\mathrm{L} 3)_{2}(\mathrm{pic})\right]^{\mathrm{a}}$ & $\begin{array}{l}368 \mathrm{~nm}(262.7 \pm 3.8 \mathrm{~ns}) \\
383 \mathrm{~nm}(245.7 \pm 3.6 \mathrm{~ns})\end{array}$ & $\begin{array}{l}410 \mathrm{~nm}(253.6 \pm 0.7 \mathrm{~ns}) \\
460 \mathrm{~nm}(274.1 \pm 0.3 \mathrm{~ns}) \\
649 \mathrm{~nm}(275.3 \pm 2.3 \mathrm{~ns})\end{array}$ \\
\hline$\left[\operatorname{lr}(\mathrm{L} 4)_{2}(\mathrm{pic})\right]^{\mathrm{a}}$ & 375 nm (264.8 \pm 7.3 ns $)$ & $\begin{array}{l}402 \mathrm{~nm}(270.4 \pm 0.9 \mathrm{~ns}) \\
430 \mathrm{~nm}(260.2 \pm 0.3 \mathrm{~ns}) \\
450 \mathrm{~nm}(252.9 \pm 0.3 \mathrm{~ns}) \\
628 \mathrm{~nm}(304.6 \pm 2.5 \mathrm{~ns})\end{array}$ \\
\hline$\left[\operatorname{Ir}(\mathrm{L} 5)_{2}(\mathrm{pic})\right]^{\mathrm{a}}$ & 375 nm (324.7 \pm 7.9 ns) & $\begin{array}{l}433 \mathrm{~nm}(326.3 \pm 0.5 \mathrm{~ns}) \\
455 \mathrm{~nm}(336.6 \pm 0.9 \mathrm{~ns}) \\
610 \mathrm{~nm}(328.9 \pm 3.1 \mathrm{~ns})\end{array}$ \\
\hline$\left[\operatorname{lr}(\mathrm{L} 6)_{2}(\mathrm{pic})\right]^{\mathrm{a}}$ & 375 nm (292.4 $\pm 4.6 \mathrm{~ns})$ & $\begin{array}{l}440 \mathrm{~nm}(297.5 \pm 0.5 \mathrm{~ns}) \\
470 \mathrm{~nm}(296.5 \pm 0.4 \mathrm{~ns})\end{array}$ \\
\hline$\left[\operatorname{Ir}(\mathrm{L} 7)_{2}(\mathrm{pic})\right]^{\mathrm{a}}$ & $375 \mathrm{~nm}(240.8 \pm 4.0 \mathrm{~ns})$ & $\begin{array}{l}430 \mathrm{~nm}(280.6 \pm 0.4 \mathrm{~ns}) \\
460 \mathrm{~nm}(268.1 \pm 0.4 \mathrm{~ns})\end{array}$ \\
\hline$\left[\operatorname{lr}(\mathrm{L} 2)_{2}(\mathrm{pyz})\right]^{\mathrm{a}}$ & $372 \mathrm{~nm}(392.8 \pm 15.2 \mathrm{~ns})$ & $\begin{array}{l}419 \mathrm{~nm}(343.0 \pm 3.9 \mathrm{~ns}) \\
454 \mathrm{~nm}(382.2 \pm 4.1 \mathrm{~ns}) \\
585 \mathrm{~nm}(372.1 \pm 2.9 \mathrm{~ns})\end{array}$ \\
\hline$\left[\operatorname{lr}(\mathrm{L} 5)_{2}(\mathrm{pyz})\right]^{\mathrm{a}}$ & $370 \mathrm{~nm}(328.8 \pm 4.0 \mathrm{~ns})$ & $\begin{array}{l}431 \mathrm{~nm}(349.1 \pm 1.7 \mathrm{~ns}) \\
459 \mathrm{~nm}(360.8 \pm 1.3 \mathrm{~ns}) \\
604 \mathrm{~nm}(380.0 \pm 1.1 \mathrm{~ns})\end{array}$ \\
\hline$\left[\operatorname{lr}(\mathrm{L} 7)_{2}(\mathrm{pyz})\right]^{\mathrm{a}}$ & $355 \mathrm{~nm}(341.98 \pm 4.6 \mathrm{~ns})$ & $\begin{array}{l}440 \mathrm{~nm}(342.1 \pm 0.8 \mathrm{~ns}) \\
550 \mathrm{~nm}(395.2 \pm 2.1 \mathrm{~ns})\end{array}$ \\
\hline$\left[\operatorname{lr}(\mathrm{L} 2)_{2}(\text { pic })\right]^{\mathrm{b}}$ & 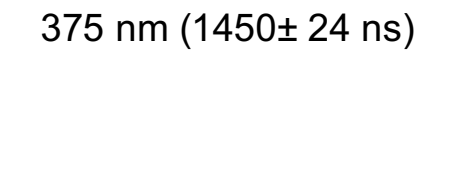 & $\begin{array}{c}400 \mathrm{~nm}(1345 \pm 26 \mathrm{~ns}) \\
410 \mathrm{~nm}(1284 \pm 11 \mathrm{~ns}) \\
460 \mathrm{~nm}(1285 \pm 5 \mathrm{~ns}) \\
600 \mathrm{~nm}(1267 \pm 11 \mathrm{~ns})\end{array}$ \\
\hline$\left[\operatorname{lr}(\mathrm{L} 2)_{2}(\mathrm{pyz})\right]^{\mathrm{b}}$ & 372 nm (2159 \pm 200 ns $)$ & $\begin{array}{l}419 \mathrm{~nm}(1954 \pm 40 \mathrm{~ns}) \\
454 \mathrm{~nm}(1914 \pm 33 \mathrm{~ns}) \\
585 \mathrm{~nm}(1836 \pm 34 \mathrm{~ns})\end{array}$ \\
\hline
\end{tabular}




\section{Conclusions}

In summary, this study has shown that heteroleptic neutral iridium(III) complexes, $\left[\operatorname{lr}(\mathrm{L})_{2}\left(\mathrm{~N}^{\wedge} \mathrm{O}\right)\right]$ (where $\mathrm{N}^{\wedge} \mathrm{O}=$ picolinate or pyrazinoate) that incorporate cyclometalated quinoxaline ligands can demonstrate tuneable emission in the long wavelength part of the visible spectrum. The emission from these complexes likely arises from a mixture of quinoxaline-centered and ${ }^{3} \mathrm{MLCT}$ excited states. A combination of spectroscopic, electrochemical, and computational analyses lends support to the assignment and sheds light on the origin of the tuneable nature of the emission. Crucially this insight shows that two strategies are available for modulating the emission energies of the complexes. Firstly, substitution of the quinoxaline ligands influences both HOMO and LUMO levels. Secondly, the ancillary picolinate or pyrazinoate ligands can modulate the HOMO level of the complex, but are unlikely to contribute to any of the excited states that are relevant to the luminescence character. This final point is noteworthy as previous work ${ }^{28}$ has suggested that the triplet excited state level of related $\mathrm{N}^{\wedge} \mathrm{O}$ ligands must be considered alongside any metal-to-ligand charge transfer characteristics. Given the ease of functionalization of these complexes, our future studies will explore the application of these $\operatorname{Ir}(I I I)$ species in bioimaging studies which can exploit the tuneability of long wavelength luminescence properties.

\section{Associated Content}

\section{Supporting Information}

The Supporting Information is available free of charge at XXX. General information on synthetic methods, characterization, computational analyses and photophysical studies, and additional figures and tables.

Information on the data underpinning the results presented here, including how to access them, can be found in the Cardiff University data catalogue at XXX. CCDC 1957545 contains X-ray crystallographic data for $\left[\operatorname{Ir}(\mathrm{L} 7)_{2}(\mathrm{pic})\right]$. This data can be obtained free of charge via http://www.ccdc.cam.ac.uk/conts/retrieving.html, or from the Cambridge Crystallographic Data Centre, Union Road, Cambridge, CB2 1EZ; fax(+44) 1223-336-033 or email: deposit@ccdc.cam.ac.uk. 


\section{Author Information}

\section{Corresponding Author}

E-mail: popesj@cardiff.ac.uk

\section{ORCID}

\section{Present Address}

S.J.A.P.: School of Chemistry, Main Building, Cardiff University, Wales, UK CF10 3AT.

Notes

The authors declare no competing financial interest.

\section{Acknowledgments}

Cardiff University (Knowledge Economy Skills Scholarship to K.A.P.) and STG Aerospace are also thanked for financial support and technical input (Dr Andrew Hallett and Dr Sean O'Kell). We would like to thank EPSRC for funding the PhD studentship of TS (grant code: EP/L504749/1). We thank the staff of the EPSRC Mass Spectrometry National Service (Swansea University) and the EPSRC UK National Crystallographic Service at the University of Southampton.

Table of Contents ONLY
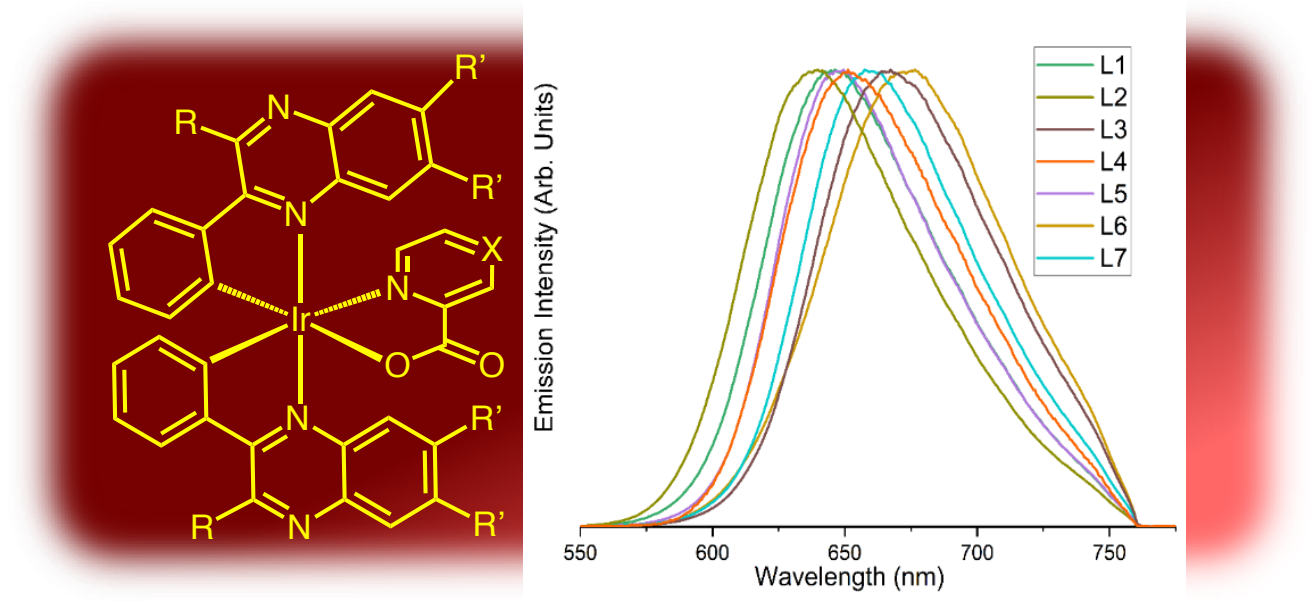

TOC text 
Heteroleptic neutral iridium(III) complexes, $\left[\operatorname{Ir}(\mathrm{L})_{2}\left(\mathrm{~N}^{\wedge} \mathrm{O}\right)\right]$ (where $\mathrm{N}^{\wedge} \mathrm{O}=$ picolinate or pyrazinoate) that incorporate cyclometalated quinoxaline ligands demonstrate tuneable emission in the red region of the visible spectrum.

\section{References}

${ }^{1}$ Iridium(III) in Optoelectronic and Photonics Applications; Zysman-Colman, E., Ed.; John Wiley \& Sons, Inc: Chichester, West Sussex, 2017.

2 a) Lo, K.K-W.; Ng, D.C-M.; Chung, C-K. First examples of luminescent cyclometalated iridium(III) complexes as labeling reagents for biological substrates Organometallics 2001, 20, 4999-5001; b) Zhao, Q. ; Huang, C.; Li, F. Phosphorescent heavy-metal complexes for bioimaging Chem. Soc. Rev. 2011, 40, 2508-2524; c) Baggaley, E.; Gill, M. R.; Green, N. H.; Turton, D.; Sazanovich, I. V. Botchway, S. W.; Smythe, C.; Haycock, J. W.; Weinstein, J. A.; Thomas, J. A. Dinuclear ruthenium(II) complexes as two-photon, time-resolved emission microscopy probes for cellular DNA Angew. Chem. Int. Ed. 2014, 53, 3367-3371; d) Coogan, M.P.; Fernandez-Moreira, V. Progress with, and prospects for, metal complexes in cell imaging Chem. Commun. 2014, 50, 384-399; e) McKenzie, L.K.; Sazanovich, I.V.; Baggaley, E.; Bonneau, M.; Guerchais, V.; Williams, J.A.G.; Weinstein, J.A.; Bryant, H.E.; Metal Complexes for two-photon photodynamic therapy: a cyclometallated iridium complex induces two-photon photosensitization of cancer cells under near-IR light Chem. Eur. J. 2017, 23, 234-238; f) Baggely, E.; Weinstein, J.A.; Williams, J.A.G. Time-Resolved Emission Imaging Microscopy Using Phosphorescent Metal Complexes: Taking FLIM and PLIM to New Lengths Struct. Bonding 2015, 165, 205-256; g) Day, A.H.; Ubler, M.H.; Best, H.L.; LloydEvans, E.; Mart, R.J.; Fallis, I.A.; Allemann, R.K.; Al-Wattar, E.A.H.; Keymer, N.I.; Buurma, N.J.; Pope, S.J.A. Targeted cell imaging properties of a deep red luminescent iridium(III) complex conjugated with a c-Myc signal peptide Chem. Sci. 2020 DOI: $10.1039 / c 9 s c 05568$ A

3 a) Lamansky, S.; Djurovich, P.; Murphy, D.; Abdel-Razzaq, F.; Lee, H-E.; Adachi, C.; Burrows, P. E.; Forrest, S. R.; Thompson, M. E. Highly Phosphorescent BisCyclometalated Iridium Complexes: Synthesis, Photophysical Characterization, and Use in Organic Light Emitting Diodes J. Am. Chem. Soc. 2001, 123, 4304-4312; b) 
Ma, D.; Liu, R.; Zhang, C.; Qiu, Y.; Duan, L. High-efficiency organic light emitting diodes based on sublimable cationic iridium(III) complexes with sterically hindered spaces ACS Photonics 2018, 5, 3428-3437; c) Ma, D.; Zhang, C.; Liu, R.; Qiu, Y.; Duan, L. Controlling ion distribution for high performance organic light emitting diodes based on sublimable cationic iridium(III) complexes ACS Appl. Mater. Interfaces 2018, 10, 29814-29823; d) Tordera, D.; Pertegas, A.; Shavaleev, N.M.; Scopelliti, R.; Orti, E.; Bolink, H.J.; Baranoff, E.; Gratzel, M.; Nazeeruddin, M.K. Efficient orange light-emitting electrochemical cells J. Mat. Chem. 2012, 22, 1926419268; e) Mills, I.N.; Porras, J.A.; Bernhard, S. Judicious design of cationic, cyclometalated $\operatorname{Ir}(\mathrm{III})$ complexes for photochemical energy conversion and optoelectronics Acc. Chem. Res. 2018, 15, 352-364.

${ }^{4}$ a) Prier, C.K.; Rankic, D.A.; MacMillan, D.W.C. Visible Light Photoredox Catalysis with Transition Metal Complexes: Applications in Organic Synthesis Chem. Rev. 2013, 113, 5322-5363; b) Zuo, Z.; Ahneman, D.T.; Chu, L.; Terrett, J.A.; Doyle, A.G.; MacMillan, D.W.C. Merging photoredox with nickel catalysis: Coupling of $\alpha-$ carboxyl sp33-carbons with aryl halides Science 2014, 345, 437-440; c) Hallet, A.J.; White, N.; Wu, W.; Cui, X.; Horton, P.N.; Coles, S.J.; Zhao, J.; Pope, S.J.A. Enhanced photooxidation sensitizers: the first examples of cyclometalated pyrene complexes of iridium(III) Chem. Commun. 2012, 48, 10838-10840.

${ }^{5}$ Li, Y.; Dandu, N.; Liu, R.; Hu, L.; Kilina, S.; Sun, W. Nonlinear Absorbing Cationic Iridium(III) Complexes Bearing Benzothiazolylfluorene Motif on the Bipyridine $(\mathrm{N} \wedge \mathrm{N})$ Ligand: Synthesis, Photophysics and Reverse Saturable Absorption ACS Appl. Mater. Interfaces 2013, 5, 6556-6570.

${ }^{6}$ a) Sheet, S.J.; Sen. B.; Khatua, S. Organoiridium(III) complexes as luminescence color switching probes for selective detection of nerve agent simulation in solution and vapor phase Inorg. Chem. 2019, 58, 3635-3645; b) Law, W.H-T.; Leung, K-K.; Lee, L.C-C.; Poon, C-S.; Liu, H-W.; Lo, K.K-W. Cyclometalated Iridium(III) BipyridylPhenylenediamine Complexes with Multicolor Phosphorescence: Synthesis,

Electrochemistry, Photophysics, and Intracellular Nitric Oxide Sensing ChemMedChem. 2014, 9, 1316-1329; c) Lo, K.W-W.; Li, S.P-Y.; Zhang, K.Y. Development of luminescent iridium(III) polypyridine complexes as chemical and biological probes New J. Chem. 2011, 35, 265-287.

${ }^{7}$ a) Singh-Rachford, T.N.; Castellano, F.N. Photoupconversion based on sensitized triplet-triplet annihilation Coord. Chem. Rev. 2010, 254, 2560-2573; b) Phillips, K.A.; 
Stonelake, T.M.; Chen, K.; Hou, Y.; Zhao, J.; Coles, S.J.; Horton, P.N.; Keane, S.J.; Stokes, E.C.; Fallis, I.A.; Hallett, A.J.; O’Kell, S.P.; Beames, J.B.; Pope, S.J.A. Ligand-tuneable, red-emitting iridium(III) complexes for efficient triplet-triplet annihilation upconversion performance Chem. Eur. J. 2018, 24, 8577-8588; c) Sun, J.; Wu, W.; Zhao, J. Long-Lived Room-Temperature Deep-Red-Emissive Intraligand Triplet Excited State of Naphthalimide in Cyclometalated Ir(III) Complexes and its Application in Triplet-Triplet Annihilation-Based Upconversion Chem. Eur. J. 2012, $18,8100-8112$

${ }^{8}$ Henwood, A.F.; Zysman-Colman, E. Lessons learned in tuning the optoelectronic properties of phosphorescent iridium(III) complexes Chem. Commun. 2016, 53, 807826

9 a) Lai, P-N.; Teets, T.S. Ancillary ligand effects on red-emitting cyclometalated iridium complexes Chem. Eur. J. 2019, 25, 6026-6037; b) Lai, P-N.; Brysacz, Alam, M.K.; Ayoub, N.A.; Gray, T.G.; Bao, J.; Teets, T.S. Highly efficient red-emitting biscyclometalated iridium complexes J. Am. Chem. Soc. 2018, 140, 10198-10207. ${ }^{10}$ Ladouceur, S.; Zysman-Colman, E. A Comprehensive Survey of Cationic Iridium(III) Complexes Bearing Nontraditional Ligand Chelation Motifs Eur. J Inorg. Chem. 2013, 2985-3007

${ }^{11}$ For example, Hierlinger, C.; Roisnel, T.; Cordes, D.B.; Slawin, A.M.Z.; Jacquemin, D.; Guerchais, V.; Zysman-Colman, E. An unprecedented family of luminescent iridium(III) complexes bearing a six-membered chelated tridentate $\mathrm{C}^{\wedge} \mathrm{N}^{\wedge} \mathrm{C}$ ligand Inorg. Chem. 2017, 56, 5182-5188

12 Li, G.M.; Zhu, D.X.; Peng, T.; Liu, Y.; Wang, Y.; Bryce, M.R. Very High Efficiency Orange-Red Light-Emitting Devices with Low Roll-Off at High Luminance Based on an Ideal Host-Guest System Consisting of Two Novel Phosphorescent Iridium Complexes with Bipolar Transport Adv. Funct. Mater. 2014, 24, 7420-7426. ${ }^{13}$ For example, Li, D.; Yan, X.; Hu, Y.; Liu, Y.; Guo, R.; Liao, M.; Shao, B.; Tang, Q.; Guo, X.; Chai, R.; Zhang, Q.; Tang, M. Two-photon image tracking of neural stem cells via iridium complexes encapsulated in polymeric nanospheres ACS Biomaterials Sci. Eng. 2019, 5, 1561-1568.

14 Tsuboyama, A.; Iwawaki, H.; Furugori, M.; Mukaide, T.;Kamatani, J.; Igawa, S.; Moriyama, T.; Miura, S.; Takiguchi, T.; Okada, S.; Hoshino, M.; Ueno, K. Homoleptic Cyclometalated Iridium Complexes with Highly Efficient Red Phosphorescence and 
Application to Organic Light-Emitting Diode J. Am. Chem. Soc. 2003, 125, 12971-12979.

15 a) Su, Y.J.; Huang, H.L.; Li, C.L.; Chien, C.H.; Tao, Y.T.; Chou, P.T.; Datta, S.; Liu, R.S. Highly Efficient Red Electrophosphorescent Devices Based on Iridium Isoquinoline Complexes: Remarkable External Quantum Efficiency Over a Wide Range of Current Adv. Mater. 2003, 15, 884-888; b) Li, C.L.; Su, Y.J.; Tao, Y.T.; Chou, P.T.; Chien, C.H.; Cheng, C.C.; Liu, R.S. Yellow and Red Electrophosphors Based on Linkage Isomers of Phenylisoquinolinyliridium Complexes: Distinct Differences in Photophysical and Electroluminescence Properties Adv. Funct. Mater. 2005, 15, 387-395; c) Huo, S.; Deaton, J.C.; Rajeswaran, M.; Lenhart, W.C. Highly Efficient, Selective, and General Method for the Preparation of Meridional Homoand Heteroleptic Tris-cyclometalated Iridium Complexes Inorg. Chem. 2006, 45, 3155-3157.

${ }^{16}$ Li, G-N.; Dou, S-B.; Zheng, T.; Chen, X-Q.; Yang, X-H.; Wang, S.; Sun, W.; Chen, G-Y.; Mo, Z-R.; Niu Z-G. Orange-Red Phosphorescent Iridium(III) Complexes Bearing Bisphosphine Ligands: Synthesis, Photophysical and Electrochemical Properties, and DFT Calculations Organometallics 2018, 37, 78-86 17 a) Guo, J.; Zhou, J.; Fu, G.; He, Y.; Li, W.; Lu, X. Two efficient near-infrared (NIR) luminescent $\left[\operatorname{Ir}\left(\mathrm{C}^{\wedge} \mathrm{N}\right) 2\left(\mathrm{~N}^{\wedge} \mathrm{O}\right)\right]$ characteristic complexes with 8-hydroxyquinoline (8HQ) as the ancillary ligand Inorg. Chem. Commun. 2019, 101, 69-73; b) Li, C-J.; Yin, S-Y.; Wang, H-P.; Wei, Z-W.; Pan, M. Tuning Colorful luminescence of iridium(III) complexes from blue to near-infrared J. Photochem. Photobiol. A 2019, 397, 99-104; c) Phillips, K.A.; Stonelake, T.M.; Horton, P.N.; Coles, S.J.; Hallett, A.J.; O’Kell, S.P.; Beames, J.M.; Pope, S.J.A. Dual visible/NIR emission from organometallic iridium(III) complexes J. Organomet. Chem. 2019, 893, 11-20; d) Chen, H.-Y.; Yang, C.-H.; Chi, Y.; Cheng, Y.-M.; Yeh, Y.-S.; Chou, P.-T.; Hsieh, H.-Y.; Liu, C.-S.; Peng, S.-M.; Lee, G.-H. Room-temperature NIR phosphorescence of new iridium (III) complexes with ligands derived from benzoquinoxaline Can. J. Chem. 2006, 84, 309318.

18 a) Routledge, J.D.; Hallett, A.J.; Platts, J.A.; Horton, P.N.; Coles, S.J.; Pope, S.J.A. Tuning the electronics of phosphorescent, amide-functionalised, cyclometalated Ir(III) complexes: syntheses, structures, spectroscopy and theoretical studies Eur. J. Inorg. Chem. 2012, 4065-4075; b) Smith, R.A.; Stokes, E.C.; Langdon-Jones, E.E.; Platts, J.A.; Kariuki, B.M.; Hallett, A.J.; Pope, S.J.A. 
Cyclometalated cinchophen ligands on iridium(III): towards water-soluble complexes with visible luminescence Dalton Trans. 2013, 42, 10347-10357; c) Jones, J.E.; Jenkins, R.L.; Hicks, R.S.; Hallett, A.J.; Pope, S.J.A. Water-soluble, luminescent iridium(III)-ytterbium(III) complexes using dipyrido[3,2-a:2',3'-c]phenazine derivatives as bridging units Dalton Trans. 2012, 41, 1072-10381; d) Lowe, J.A.; Stacey, O.J.; Horton, P.N.; Coles, S.J.; Pope, S.J.A. Alkyl chain functionalised cyclometalated platinum(II) complexes: syntheses, luminescence properties and X-ray crystal structure J. Organomet. Chem. 2016, 805, 87-93; e) Stacey, O.J.; Platts, J.A.; Coles, S.J.; Horton, P.N.; Pope, S.J.A. Phosphorescent, cyclometalated cincophen-derived platinum complexes: syntheses, structures, and electronic properties Inorg. Chem. 2015, 54, 6528-6536; f) Stacey, O.J.; Ward, B.D.; Coles, S.J.; Horton, P.N.; Pope, S.J.A. Chromophore-labelled, luminescent platinum complexes: syntheses, structures, and spectroscopic properties Dalton Trans. 2016, 45, 10297-10307; g) Stacey, O.J.; Amoroso, A.J..; Platts, J.A.; Horton, P.N.; Coles, S.J.; Lloyd, D.; Williams, C.F.; Hayes, A.J.; Dunsford, J.J.; Pope, S.J.A. Water soluble, cyclometalated Pt(II)-Ln(III) conjugates towards novel bimodal imaging agents Chem. Commun. 2015, 51, 12305-12308 ${ }^{19}$ Langdon-Jones, E.E.; Hallett, A.J.; Routledge, J.D.; Crole, D.A.; Ward, B.D.; Platts, J.A.; Pope, S.J.A. Using substituted cyclometalated quinoxaline ligands to finely tune the luminescence properties of iridium(III) complexes Inorg. Chem. 2013, $52,448-456$.

20 a) Schneidenbach, D.; Ammermann, S.; Debeaux, M.; Freund, A.; Zollner, M.; Daniliuc, C.; Jones, P.G.; Kowalsky, W.; Johannes, H-H. Efficient and long-time stable red iridium(III) complexes for organic light emitting diodes based on quinoxaline ligands Inorg. Chem. 2010, 49, 397-406; b) Jing, Y-M.; Wang, F-Z.; Zheng, Y-X.; Zuo, J-L. Efficient deep red electroluminescence of iridium(III) complexes with 2,3diphenylquinoxaline derivatives and tetraphenylimidodiphosphinate J. Mater. Chem. C 2017, 5, 3714-3724; c) Sun, W.; Pei, C.; Lu, T.; Cui, P.; Li, Z.; McCleese, C.; Fang, Y.; Kilina, S.; Song, Y.; Burda, C. Reverse saturable absorbing cationic iridium(III) complexes bearing the 2-(2-quinolinyl)quinoxaline ligand: effects of different cyclometalating ligands on linear and non-linear absorption J. Mater. Chem. C 2016, 4, 5059-5072; d) Tani, K.; Fujii, H.; Mao, L.; Sakurai, H.; Hirao, T. Iridium(III) complexes bearing quinoxaline ligands with efficient red luminescence properties Bull. Chem. Soc. Jap. 2007, 80, 783-788. 
${ }^{21}$ Phillips, K.A. Development of luminescent iridium(III) and rhenium(I) complexes for optoelectronic applications, Ph.D. Dissertation, Cardiff University, Cardiff, UK, 2019. ${ }^{22}$ Nonoyama, M. Benzo[h]quinolin-10-yl-N Iridium(III) Complexes Bull. Chem. Soc. Jap. 1974, 47, 767-768

${ }^{23}$ Coles, S.J.; Gale, P.A. Changing and challenging times for service crystallography Chem. Sci. 2012, 3, 683-689.

${ }^{24}$ a) Lowry, M.S.; Bernhard, S. Synthetically tailored excited states: phosphorescent cyclometalated iridium(III) complexes and their applications Chem. Eur. J. 2006, 12, 7970-7977; b) Adeloye, A.O.; Mphahlele, M.J.; Adekunle, A.S.; Rhyman, L.; Ramasami, P. Spectroscopic, Electrochemical and DFT Studies of Phosphorescent Homoleptic Cyclometalated Iridium(III) Complexes Based on Substituted 4Fluorophenylvinyl- and 4-Methoxyphenylvinylquinolines Materials 2017, 10, 10611082.

${ }^{25}$ Williams, J. A. G.; Wilkinson, A.J.; Whittle, V.L. Light-emitting iridium complexes with tridentate ligands Dalton Trans. 2008, 2081-2099

${ }^{26}$ Flamigni, L.; Barbieri, A.; Sabatini, C.; Ventura, B.; Barigelletti, F. Photochemistry and Photophysics of coordination compounds: iridium Top. Curr. Chem. 2007, 281, 143.

${ }^{27}$ Flamigni, L.; Ventura, B.; Barigelletti, F.; Baranoff, E.; Collin, J-P.; Sauvage, J-P. Luminescent Iridium(III)-Terpyridine Complexes - Interplay of Ligand Centred and Charge Transfer States Eur. J. Inorg. Chem. 2005, 1312-1318.

${ }^{28}$ You, Y.; Park, S.Y. Inter-Ligand Energy Transfer and Related Emission Change in the Cyclometalated Heteroleptic Iridium Complex: Facile and Efficient Color Tuning over the Whole Visible Range by the Ancillary Ligand Structure J. Am. Chem. Soc. 2005, 127, 12438-12439. 